\title{
REVIEW
}

\section{ACQUIRED RESISTANCE TO TUBERCULOUS INFECTION IN EXPERIMENTAL MODEL}

\author{
KOOMI KANAI \\ Department of Tuberculosis, National Institute of Health, Tokyo
}

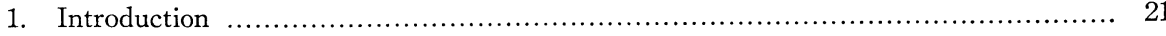

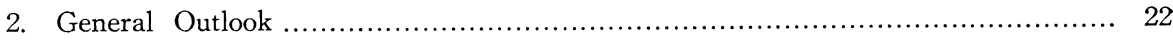

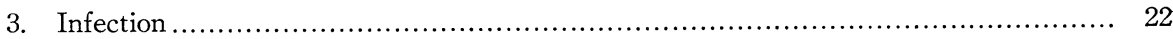

A. Morphological, Microbiological, and Immunological Aspects of Phagocytosis... 22

B. Biochemical Aspects of Phagocytosis.................................................. 24

C. In Vivo Grown Tubercle Bacilli ........................................................ 26

D. Virulence of Tubercle Bacilli.......................................................... 27

E. The Natural Course of Tuberculous Infection................................... 31

F. The Nature of Persistence of Infecting Bacilli ..................................... 34

4. Immunity (Protection) ...................................................................... 36

A. Problems of Methodology for Evaluation of Protective Antigens .............. 36

B. Protective Antigens..................................................................... 39

C. Nonspecific and Broadly-Specific Resistance to Tuberculous Infection ........... 49

D. Mechanism of Acquired Resistance to Tuberculous Infection..................... 52

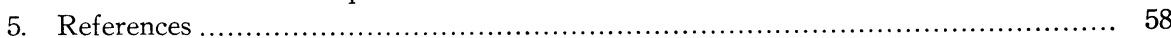

\section{INTRODUCTION}

Under the current progress of chemotherapy and vaccination, tuberculosis is apt to be considered as an already settled problem in civilized countries. In fact, the mortality due to this infectious disease has decreased so remarkably in recent years that an overoptimistic view is prevailing that tuberculosis has been overcome. However, many epidemiological, clinical and experimental observations indicate that tuberculous infections are under control in man and communities only as the result of conversion from the active state into a latent form. This situation is reflected on the well-known fact that the population of tuberculous patients is now shifting from the younger generation to the older one, majority of which being relapse cases.

Unfortunately, we have little immunological and microbiological knowledge concerning the evolution of tuberculous infection. Even more suprising is the fact that the mechanisms of natural and acquired resistance to tuberculous infection are still a matter of speculation, though there is no longer any doubt that $B C G$ vaccine is protective in man and animals. In other words, the effectiveness of BCG vaccine has been supported by empirical facts, experimental results, and epidemiological survey, but lacks an established theoretical basis.

Thus, tuberculous immunity still remains as an unsolved medical problem. At the 
same time, tuberculous infection is regarded as a very suggestive model for the study of parasitism in chronic microbial infections in general, and also as the most convenient material for the study of infectious allergy of the delayed type. In fact, our interest in these old-fashioned problems has been continuously renewed being stimulated by the advances in the related fields and also by the progress of general experimental methodology. It is not without reason that several reviews have appeared on the problems in recent years, being written from refreshed medical and biological standpoints (Youmans, 1957) (Crowle, 1958) (Weiss, 1959) (Dubos, 1964) (Lurie, 1964).

Therefore, the present review is not to look over the long history of investigations on tuberculous immunity, but to see the current interest and trends in the field, surveying only the relatively recent literature of experimental studies. More space will be allotted to the topics of my personal interest even at the sacrifice of distribution of due weight to others.

Another motive for the preparation of this review resides in Leprosy and Tuberculosis Conference held on May 18-20, 1966, in Tokyo, as a branch session of Japan-U. S. Cooperative Medical Science Program. For many years, tuberculous immunity has been a subject of mutual academic interest in both countries. And, the Conference took it up as a common research theme. Therefore, it would be worth-while to survey the literature of the two countries in comparison. Because of this consideration, the author has tried to refer to as much literature of this country as possible.

\section{General Outlook}

Tuberculous infection and immunity are, in other words, the host-parasite relationship in tuberculosis. In a chronic infection such as tuberculosis, the relationship is of such a nature that the immunology and the pathology can not be discussed separately. Behavior of infecting agents, host cell response, lesion formation, hypersensitivity, and antibodies are all interfering mutually in a delicate and dynamic fashion. In this situation it is not possible to understand the mechanisms of tuberculous infection and immunity only from the result of a single type of experiment. Various observations in varied experimental conditions must be taken together in order to make up the general picture of the evolution of infection.

Roughly speaking, investigations of tuberculous immunity will be done from two different sides; one is to see the nature of host response of vaccinated and unvaccinated animals and the other is to search for immunizing agents of the tubercle bacillus. A real immunizing agent is to be found first in order to investigate the defence mechanisms of immunized animals, but it is also true that the nature of host response must be clarified in order to establish the methodology of search for immunizing agents. This paradoxical situation is still present in this field of medical science. For the sake of convenience, however, the author will see the nature of tuberculous infection at the beginning and then proceed to the problem of protective antigens, and finally the mechanism of acquired resistance will be the subject of discussion.

\section{INFECTION}

\section{A. Morphological, Microbiological, and Immunological Aspects of Phagocytosis in Relation to Tuberculous Infection}

The tubercle bacillus is a facultative intracellular parasite capable of multiplying and 
surviving mostly within macrophages. In this connection, phagocytic events must be discussed first as the prelude of the complicated parasitism in tuberculous infection. Tubercle bacilli are rapidly phagocytosed in vivo by both neutrophiles and macrophages shortly after they enter the host and become more or less permanent residents within macrophages. In recent years, extensive studies have been done concerning dynamic aspects of phagocytosis under the current progress of methodology, as reviewed by Hirsch (1965). Phagocytosis begins with the contact between foreign material and phagocytic cell. This contact may be possible without participation of immunological factors. However, some indirect evidences are now available indicating that cytophilic antibody, probably $7 \mathrm{~S} \gamma_{2}$-globulins, can act to opsonize particulate antigens to allow their uptake by macrophages (Uhr, 1965) (Berken and Benacerraf, 1966). Of particular interest is the fact that $7 \mathrm{~S} \gamma_{2}$-globulins are produced in guinea pigs hyperimmunized by complete Freund's adjuvant (Daniel, 1965), and that the antibodies appear to have some associations with delayed hypersensitive reactions (David, Lawrence and Thomas, 1964a). In view of these infomations, the contact between tubercle bacilli and macrophages appears to be a process accelerated by the participation of delayed type hypersensitivity, and it might constitute an important part in the protective mechanism of the host. These points will be discussed later in a separate section.

The cell-bacillus contact will be followed by engulfment. The mechanism of engulfment was recently clarified by time-lapse phase-contrast cinemicroscopic observations Hirsch, 1962), and electronmicroscopic study (Lockwood and Allison, 1963) (Lockwood and Allison, 1964) (North and Mackaness, 1963a, b) (Zucker-Franklin and Hirsch, 1964). The process of engulfment is not different from that of pinocytosis. The cell membrane is invaginated about the particle, and then the membrane meet together and fuse to make a vacuole having the particle therein. There will be little doubt that the same thing will occur in the case of tubercle bacilli. As far as the limiting membrane of the vacuole remains intact, the direct contact between the ingested bacilli and the cytoplasm of phagocytic cells does not occur (Armstrong and Sword, 1966). This fact should be taken into consideration when we call tubercle bacilli an "intracellular parasite".

The bacill ingested in this way will be subjected to the digestive mechanism of the cell. As is well-known, antibacterial products and hydrolytic enzymes of phagccytic cells are contained in cytoplasmic granules or lysosomes. Therefore, it will be quite natural to suppose that if these substances are to serve for killing and digesting the engulfed bacilli, they must be released from the lysosomes to reach the inside of the phagocytic vacuole. The process like this, degranulation, has been actually demonstrated by various morphological techniques (Hirsch, 1962) (Lockwood and Allison, 1963) (North and Machaness, 1963a, b) (Zucker-Franklin and Hirsch, 1964) (Horn, Spicer and Wetzel, 1964). Here again, the membrane-fusion mechanism is playing a role for degranulation in such a manner that fusion occurs between the limiting membrane of the phagocytic vacuole and that of the lysosome after the contact of the two organizations. This mechanism provides a means for discharging the lysosomal components to the phagocytic vacuole without exposing the cell cytoplasm to autolytic action. Most bacteria are killed and destroyed inside of phagocytic cells within 10 to 15 minutes (Rowley, 1962).

However, the same is not always the case with tubercle bacilli. Not only they can resist to the bactericidal action of phagocytes, but also they can multiply and persist within phagocytes. The complexity of tuberculous infection may be originated from this fact. During the stay of tubercle bacilli within phagocytic vacuole, there will be some interactions between the bacilli and lysosomal components. As a matter of fact, 
Merckx, Brown, and Karlson (1964) observed by electronmicroscopic study a particular structure ( $\mathrm{X}$ body) in the lungs of mice infected with virulent tubercle bacilli, which they interpreted with due reasons as a result of interaction between lysosomes and the bacilli. On the other hand, Kanai (1967a) separated tubercle bacilli mechanically from infected mouse lungs and demonstrated the presence of host-originated acid phosphatase, the most representative lysosomal enzyme, bound on the bacillary surface. This will be another indication of the lysosome-parasite interaction in tuberculous infection.

Nevertheless, we are still ignorant of what lysosomal components are really antibacterial, if not bactericidal, against tubercle bacilli. Besides hydrolyzing enzymes, the lysosome of neutrophiles has basic protein which has an antibacterial activity against a variety of microorganisms (Zeya and Spitznagel, $1966 \mathrm{a}, \mathrm{b}$ ). However, evidences are still unavailable at this moment showing that the lysosomes of macrophages have the same substances and they are antibacterial against tubercle bacilli. Lysozyme is also known to be localized in cytoplasmic granules and discharged into the phagocytic vacuole (Spitznagel and Chi, 1963) (Leake and Myrvik, 1964). Rabbit alveolar macrophages at least are reported to contain abundant lysozyme (Myrvik, Leake and Fariss, 1961) (Myrvik, Leake and Oshima, 1962) (Cohn and Wiener, 1963a, b). In fact, there have been several reports indicating that lysozyme is tuberculostatic playing a significant role in the resistance to tuberculous infection (Myrvik and Weiser, 1951) (Myrvik, Weiser and Agar, 1953) (Oshima, Myrvik ane Leake, 1961). In addition, elevation of a lysozymelike substance in immunized animals has been demonstrated by Janicki and Patnode (1961). Contrary to the conventional knowledge that tubercle bacilli are not sensitive to the lytic action of lysozyme, recent studies of Thacore and Willett (1963) (1966) showed that spheroplasts of tubercle bacilli were produced in the presence of lysozyme in vitro and in tissue culture cell. The significance of this finding will be discussed later again in relation to resistance to tuberculosis and persistence of the bacilli in the host. Phagocytin is also an antibacterial substance contained in cytoplasmic granules (Hirsch, 1960 a, b). Recently, Colwell and Hess (1963) isolated a phagocytin-like agent from the sonic lysate of the peritoneal mononuclear cells which was antimycobacterial at $\mathrm{pH} 5.75$ to 6.2 .

As the final topic concerning degranulation, the participation of antigen-antibody reaction in some instances will be worthy of mentioning. Dumonde et al. (1965) reported that combination of antibody with the surface membranes of viable ascites tumor cells induced lysosomal activation (release of acid phosphatase) and unmasking of cytoplasmic phospholipid, and that this lysosomal response of viable cells to antigen-antibody reaction at the plasma membranes may require the operation of mechanisms dependent on the organization of whole cells. This information, taken together with the possible preparatory role of cytophilic antibody in phagocytosis, may provide an important suggestion regarding the mechanism of cellular immunity in tuberculosis.

\section{B. Biochemical Aspects of Phagocytosis in Relation to Tuberculosus Infection}

During the process of particle ingestion, the metabolism of phagocytes is stimulated greatly (Sbarra and Karnovsky, 1959) (Cohn and Morse, 1960). Glycolysis appears to play a main role at least in neutrophils to obtain energy for phagocytosis even under aerobic condition (Karnovsky, 1962). The oxidative system for glucose dissimilaticn may be operative to a much lesser extent. Accordingly, a large amount of lactic acid is produced in neutrophiles. This might account for the fact that internal $\mathrm{pH}$ of leucccytes 
is quite low, especially in the vicinity of ingested material (Rouse, 1925a, b) (Ishikawa, 1936). In the light of the recent knowledges of phagocytosis (Hirsch, 1965), internal $\mathrm{pH}$ might be the $\mathrm{pH}$ within phagocytic vacuole. Otherwise, the metabolism of phagocytic cells would be impaired greatly. Of course, whether or not lactic acid as a metabolite is discharged into phagocytic vacuole is unknown at this time. This point might be an interesting subject of study in future, because Dubos has pointed out that lactic acid may exert a growth-inhibitory action upon tubercle bacilli in vivo (Dubos, 1954).

Furthermore, Rossi and Zatti (1961) (1964) have conducted a detailed investigation concerning the metablic activity of guinea pig neutrophiles during phagocytosis, particularly in respect of glucose consumption, lactate production, and $\mathrm{NADH}$ turn over in aerobic and anaerobic conditions. Phagocytosis also leads to increased turn over rates for neutral lipids and phospholipids in the cells (Elsbach, 1959) (Karnovsky and Wallach, 1961), which might suggest synthesis of new membrane or other substances needed for performance of phagocytosis.

Knowledge concerning the metabolism of monccytes and macrophages is quite sparse, though it is believed that the metabolic pathways similar to those in neutrophiles are operative. Glucose utilization and oxygen consumption of macrophages are somewhat higher than in neutrophiles (Stähelin, Suter and Karnovsky, 1956). Recently, Allison, Zappasodi and Lurie (1962) reported that the metabolic activity of the mononuclear cells of immunized rabbits and genetically resistant rabbits is greater than that of normal cells. It appears still difficult, however, to correlete those biochemical findings with the process of tuberculous infection and the mechanism of protection.

Recent evidences suggest that various types of mononuclear phagccytes may differ in their metabolism. For example, alveolar macrophages show greater respiratory activity and lysozyme content than the other phagocytic cells (Oren et al., 1963) (Myrvik, Leake and Fariss, 1961). In this regard, it will be interesting to note that the extent of multiplication of tubercle bacilli in vivo is different from one organ to another ; for example, it is remarkable in the spleen but not in the lungs of guinea pigs, and vice versa in mice. This kind of difference should be explained in future in terms of the physiological difference of the phagocytic cells located in various organs.

Besides, since tubercle bacilli are residents within the phagocytic vacuole of macrophages, we need the biochemical and physiological knowledges of this structure for the proper understanding of tuberculous infection. However, we have been quite ignorant thereof, excepting the fact that lysosomal hydrolysing enzymes are discharged therein. These enzymes include peroxidase, alkaline and acid phosphatase, acid ribonuclease, acid deoxyribonuclease, lipases, proteinases, beta-glucuronidase and lysozyme. Among them, acid phosphatase has been most frequently investigated in association with tuberculous infection.

Grogg and Pearce (1952) reparted that acid phosphatase activity was strong, when examined histochemically, in the macrophages of animals genetically resistant to tuberculosis. Weiss and Fawcett (1953) observed cytochemically that chicken macrophages in tissue culture were specifically stained by acid phosphatase activity. Then, Thorbecke et al. (1961) reported that Kupffer cells in the mouse liver were specifically positive in acid phosphatase staining and the activity was elevated by BCG vaccination. Suter and Hulliger (1960), Allison et al. (1961), Kanai (1964), Saito and Suter (1965) are also in agreement that acid phosphatase activity is elevated in animals immunized or infected with tubercle bacilli, and also in animals genetically resistant to tuberculosis. Never- 
theless, it is too early to conclude that this enzyme activity is an expression of host defense mechanisms against tuberculous infection. It will be a more unprejudiced view that the elevated acid phosphatase activity is only an indication of lysosomal response of phagocytic cells to the ingested tubercle bacilli.

\section{In Vivo Grown Tubercle Bacilli}

Some description has already been made that we can learn some aspects of the hostparasite interaction through the study of in vivo grown tubercle bacilli (Kanai, 1967a). With this concept in mind, such investigations in the past will be reviewed here.

This line of investigation was initiated by Segal and Bloch (1956), who was interested in the possible difference between in vivo and in vitro grown tubercle bacilli as suggested by the preliminary observations of Anderson et al. (1943) and Sheehan and Whitewell (1949). They devised a procedure to separate and collect the bacilli by differential centrifugation from the lung homogenate of moribund mice infected intravenously with a massive amount of H37Rv tubercle bacilli. The first observation concerning thus obtained in vivo bacilli (H37RvL) was that they were more virulent for mice than a corresponding suspension of in vitro cultured H37Rv. In addition, it was found that H37RvL was extremely poor in the substrate response of oxygen consumption in comparison with $\mathrm{H} 37 \mathrm{Rv}$, though the endogenous respiration was the same in both. This observation stimulated Israeli workers to a more extensive study, which was finally led to a problem of tissue metabolism in tuberculosis diverting from the original purpose. Bekierkunst and Artman (1959) studied the hydrogen transfer capacity of cell-free extracts of H37RvL separated by almost the same method as Segal and Bloch (1956), using the reduction of triphenyltetrazolium as an indicator. They found that the extract has no dehydrogenase activity in the presence of lactate, malate or pyruvate, whereas extracts from H37Rv or BCG grown in vitro were active. This result suggested a possibility that an inhibitor might be present in the extract which was responsible for the lack of substrate response. Shortly after that, they found the inhibitor and identified it as NADase originated from the mouse lung tissue (Bekierkunst and Artman, 1960) (Artman and Bekierkunst, 1961 a, b). In fact, NADase level in the tissue of tuberculous mouse increased up to 2 to 3 folds of that of normal mice and NAD content in the liver decreased down to one half. The activity of NAD-linked dehydrogenases decreased of course (Bekierkunst and Artman, 1962). Then, these authors turned to the investigation of tissue metabolism of tuberculous infection. This will be discussed in a separate section. However, the problem with which we are concerned at this moment is that host-originated NADase is present probably on the surface of in vivo grown tubercle bacilli inhibiting their enzyme activity. NADase is a particulate enzyme, $80 \%$ being microsomal and $20 \%$ nuclear in normal mice. In tuberculous mice, however, $10 \%$ of NADase is found in the soluble fraction (Bekierkunst, Artman and Silman, 1964). Then, question is raised which kind of NADase is present on the bacillary surface, soluble or particulate. Unlike the case of lysosomal enzymes, it is still difficult to interpret the above observation in association with phagocytic events.

In addition to the host-originated NADase as a factor responsible for the low respiration of in vivo tubercle bacilli, another finding was obtained by Kusaka, Sato and Shoji (1964), who demonstrated the lack of cytochrome components in M. lepromurium and BCG which were reharvested from the omentum of guinea pigs injected intraperitoneally with a massive dose of in vitro cultured cells of the same strain. However, there 
will be a possibility that the lack of cytochrome components is a secondary phenomenon of the growth of the bacilli in oxygen-limited in vivo environment.

Pokorony and Sulová (1962) improved the separation technique of in vivo bacilli by the use of density gradient centrigugation, and then Pokorony (1962) studied the lipids of thus separated bacilli. It was found that the bacilli in vivo synthesized much fewer lipids in general, fats in particular, than when they were grown in artificial liquid medium. They also displayed the characteristic changes of composition of higher fatty acids, which are basic building blocks for lipids. The strain grown in mice failed to produce 2 higher fatty acids with more than 30 carbon atoms which the same strains grown on Sauton medium produced regularly. However, the presence of 2 other acids with 20 and 22 carbons was demonstrated. Interesting is the fact that a similar decrease of lipid content was demonstrated also of in vitro cultured bacilli when glycerol in Sauton medium was replaced with glucose or lactic acid, or when grown under anaerobic condition. On the other hand, Kanai, Wiegeshaus, and Smith (1965) could detect by the combined use of column chromatography and infrared spectrography the presence of mycolic acid and phthiocerol dimycocerosate in in vivo grown $M$. bovis (Ravenel) isolated from the infected mouse lungs, and again mycolid acid from $M$. paratuberculosis isolated from the intestinal mucosa of the naturally and experimentally infected cattles. Much earlier than these investigations, Segal and Blcch (1957) showed that in vivo grown tubercle bacilli were more hydrophylic and had a lower amount of chloroform-soluble lipids than those grown in vitro. Besides, contrary to the conventional concept, the in vivo bacilli killed by phenol were less immunogenic in mice than those grown in vitro and killed in the same way. This preliminary observaticn was further confirmed by Segal himself later (1965a, b).

Then, the reviewer would like to emphasize again the passibility that in vivo grown tubercle bacilli might be bound with host-originated substances as revealed by the increased resistance to $\mathrm{NaOH}$ treatment and by the presence of lysosomal acid phosphatase on their surface (Kanai, 1967a, b). The coating of infecting tubercle bacilli with lysosomal components, which are not always destructive against the bacilli, will bring the host-parasite relationship in tuberculosis into a very complicated one, involving two possibilities at least. One is that such bacilli might act to induce cell autolysis when they come into contact with the cytoplasm of the host cell as the result of destruction of the limiting membrane of the phagocytic vacuole. The other possibility is that the foreignness of the bacilli will be masked by the host substances, which may be favourable for the bacilli to survive in the host. These points will be an interesting subject of study in future.

Last of all, a word of caution should be added here saying that in vivo grown bacilli may differ in their properties depending on their growth phase in the host, and also on the nature of environment from where the bacilli are separated. For instance, the bacilli within phagocytic cells may be greatly different from those growing on the surface of caseous material in the tuberculous cavity, though such experimental data are not available at this moment.

\section{Virulence of Tubercle Bacilli}

Virulence in the present discussion is defined as the ability of microorganisms to multiply in a host, to survive, and to cause a progressive disease. However, the bacillary multiplication is considered as a net result of the complicated competition between 
the host and the bacilli, particularly in the case of chronic infections such as tuberculosis, brucellosis, or leprosy. Morphological, biochemical, metabolic, and immunological factors of both host and parasite must be taken together into consideration for the proper understanding of virulence. In this sense, virulence is not a static idea, but a dynamic concept of the physiology of in vivo growing tubercle bacilli in relation to the normal and pathologic conditions of the host.

For their multiplication and survival in the host, tubercle bacilli must be equipped with solid surface structure which can resist the digestive and destructive mechanisms of the host, and also must be endowed with the metabolic machinery through which they can synthesize their constituents and obtain energy for activity and reproduction receiving nutrients from surrounding environments. In addition to these, factors by which tubercle bacilli can cause anatomical and biochemical lesions in the host must be considered for their virulence.

a) Metabolic aspects of virulence of tubercle bacilli.

For mycobacteria in general, Hanks and Gray (1956) have shown that there is a pattern of diminishing oxidative responce to various substrates correlating with the virulence, saprophytes being the highest in the response and murine leprosy bacilli in the lowest. Such tendency had also been demonstrated by Geronimus and Birkeland (1951) among the stains, H37Rv, R1Rv, BCG, H37Ra, M. phlei, and M. smegmatis (607). These authors used formate, acetate, propionate, butyrate, and lactate as substrates of oxygen consumption. On the other hand, Bloch (1950a), and Patnode, Wrinkle and Beasley (1954) used various oxidation-reduction dyes for the determination of virulence of mycobacteria in vitro. In all of these instances, there was an inverse proportionality between the relative virulence of strains of tubercle bacilli and their readiness to react to a given dye. In connection with these investigations, it will be worth-while to refer to the papers of Heplar et al. (1954) and Guy, Raffel and Ciifton (1954). These authors demonstrated that virulent strains not only have a lower respiratory rate than avirulent strains, but also their respiration is not inhibited so much at lower oxygen tensions as that of avirulent organisms. The same is true for growth rates in vivo (Sever \& Youmans, 1957a). Lower oxygen tensions affect the multiplication of virulent strains to a lesser degree than that of attenuated or avirulent organisms. Besides, there has been some reports that tubercle bacilli need the optimum oxygen tension for their satisfactory growth, excessive oxygen being growth-inhibitory for the bacilli (Novy and Soule, 1925) (Knox, et al., 1961) (Gottlieb, et al., 1964). The optimal oxygen tension was reported by Lebek (1959) to be lower in $M$. bovis than in $M$. tuberculosis, though BCG and Ravenel were exceptional. Lyon, Lichstein and Hall (1961) demonstrated that the growth of tubercle bacilli was inhibited by aeration in the culture medium added with glucose as the carbohydrate source instead of glycerol. Kanai (1963) confirmed and extended this observation indicating that avirulent strains were more sensitive to such aeration than virulent strains.

The response of tubercle bacilli to oxygen as discussed above can be explained to some extent by the recent investigations of Bastarrachea, Anderson and Goldman (1961) and Indira and Remakrishnan (1963). These authors demonstrated the presence of a functional glycolytic system in tubercle bacilli, contrary to the conventional understanding that tubercle bacilli are a strict aerobe (Youmans, 1957) (Middlebrook, 1965). Of utmost interest is the observation of Ramakrishnan, Indira and Maller (1962) who studied the relative extent to which the two strains, H37Rv and H37Ra, dissimilates glucose by 
the glycolytic and oxidative pathways. It was found by them that the virulent strain dissimilates glucose by the glycolytic pathway to a greater extent than the avirulent strain. This metabolic property of the virulent strain might account for the fact that it can multiply and survive in the host more successfully than the avirulent strain, even in an increasingly anaerobic condition of the developing lesions.

Being concerned with other species of bacteria, the similar situation had already been observed in Pasteurella pestis (Santer and Ajl, 1955a, b) (Issaly, Issaly and Stoppani, 1961). Pasteurella pestis has both the glycolytic and oxidative systems for glucose dissimilation, the former being functional in resting cells and the latter being active in growing cells. In the avirulent strain (Pasteurella multocida), however, the pentose phosphate shunt (oxidative system) was found to be operative in both resting and multiplying cells. These informations suggest a possibility that virulent tubercle bacilli may survive in host tissue or within macrophages adapting themselves to such environments by altering their metabolic behavior from oxidative to glycolytic in response to decreased oxygen tension. As a matter of fact, in vivo grown tubercle bacilli as separated mechanically from the mouse lungs were extremely poor in substrate response of oxygen consumption and also in hydrogen-transport activity (Segal and Bloch, 1956) (Bekierkunst and Artman, 1959). In this respect, in vivo grown tubercle bacilli are very similar to $M$. lepromurium and perhaps also to human leprosy bacilli.

Another topic concerning the metabolic aspect of the virulence of tubercle bacilli is concerned with isoniazid-resistance. Most isoniazid-resistant strains are very low in virulence for guinea pigs, as first observed by Middlebrook and Cohn (1953), although this is not always true for other species of animals including man (Bloch, Widelock and Peizer, 1953) (Meissner, 1956) (Debre, et al., 1959). One of the characteristics of such drug-resistant mutants is that they have a reduced catalase activity. Although there could be some exceptions, there is generally a good correlation between low catalase activity, low virulence for guinea pigs, and high isoniazid-resistance of tubercle bacilli. Thus, this particular strain must be a very useful material to analyze the nature of virulence of tubercle bacilli in biochemical terms. It is speculated that the lack of catalase and peroxidase in isoniazid-resistant bacteria makes these organisms more susceptible to hydrogen peroxide they may encounter in host tissues and that this may be a reason for their reduced virulence. In fact, the enhanced susceptibility of isoniazid-resistant tubercle bacilli to the lethal action of hydrogen peroxide has indead been demonstrated (Knox, Meadow and Worssam, 1956). Even so, however, we should have some mcre knowledges concerning the intracellular mode of multiplication and survival of tubercle bacilli before we accept the above hypothesis as being valid.

b) Cellular structures of the tubercle bacillus in association with rirulence.

As stated in the biginning of this section, it is imaginable that virulent tubercle bacilli must have for their survival in the host the surface structure which would be solid enough to resist the destructive defence mechanisms of the host. The microscopic cord formation characteristic for the virulent strains growing in artificial midia was first studied by Middlebrook, Dubos and Pierce (1947). This observation suggested the presence of some surface substance which might be more abundant in virulent strains than in attenuated and avirulent strains. Such substance was soon acknowledged by Dubos and Middlebrook (1948) as the factor which is able to bind neutral red in the form of its red salt in alkaline aqueous media. However, this line of work was then succeeded by Bloch and his associates (Bloch, 1950 b) (Noll et al., 1956) (Bloch et al., 1957), finally 
reaching the isolation of a "toxic lipid", or trehalose-6, 6'-dimycolate, which is usually called "cord factor". However, as stated by Middlebrook (1965), it is evident from the work of Suter and Dubos (1951) that cord factor is a necessary but not sufficient condition for virulence of tubercle bacilli. Besides, it is yet uncertain that cord factor is truly a surface substance responsible for cord formation of virulent tubercle bacilli. In fact, cord factor was isolated from avirulent isoniazid-resistant strain in the same quality and quantity as other virulent strains (Nagasuga, Terai and Yamamura, 1961). Detailed discussion of the toxicity of cord factor will be done later.

Then, bacterial cell wall comes into our consideration as the structure which might account for the virulence of tubercle bacilli. As is well-known, tubercle bacilli are rich in lipids, which occupy 20 to $30 \%$ of the whole cell. And, 50 to $60 \%$ of the total lipids will be found in the cell wall fraction isolated by mechanical means (Kotani, et al., 1959). Such peculiar distribution of lipids to the cell wall may contribute favorable conditions for survival of tubercle bacilli within macrophages. Though we know very little about the chemical and structural differences of the cell wall between virulent and avirulent strains of tubercle bacilli, an indirect evidence was recently furnished by Murohashi and Yoshida (1966) suggesting the possible relationship between the cell wall structure and virulence in mycobacteria. At first, these authors studied the effects of ultraviolet irradiation upon the acid-fast stain of mycobacteria. Then, they became aware that there was some correlation between the virulence of mycobacteria and the ease with which they lost acidfastness by irradiation. Saprophytic mycobacteria lost acid-fastness most easily by a short-time irradiation, but virulent strains of tubercle bacilli could resist irradiation of an even longer duration. Avirulent strains of tubercle bacilli showed an intermediate response. The most resistant mycobacteria in this respect were leprosy bacilli. This pattern of resistance to irradiation appears just the same as that of diminishing oxidative response to various substrates in the order of saprophytes, intermediates, tubercle bacilli, Johne's bacilli, murine leprocy bacilli, and perhaps finally human leprosy bacilli (Hanks and Gray, 1956). Thus it appears that in vitro evaluation of virulence of mycobacteria by either irradiation effect on acid-fastness or oxidative responce to substrates indicates their ability to survive in vivo, not their ability to multiply rapidly in susceptible animals.

The observations that spheroplasts or L-forms of mycobacteria are not acid-fast (Mattman et al., 1960) (Thacore and Willett, 1963) will be an evidence that the cell wall structute may be responsible for acid-fastness, though there is other view that the intactness of plasmic membrane is responsible for acid-fastness (Orskav, 1964).

c) Toxic substances of tubercle bacilli.

Although no exotoxin has ever been found from virulent tubercle bacilli, some chemical constituents isolated therefrom are known to be a toxic substance. However, it is rather difficult to evaluate to what extent they are playing an undismissible role in the evolution of tuberculous infection. All we know is that when these substances are injected into experimental animals, they can cause some alterations of cell and tissue metabolisms probably affecting the activity of enzymes. Cord factor is the most wellknown example of such kind. The toxicity of cord factor, trehalose-6, 6' -dimycolate, is of a delayed type and so potent that it kills adult mice in the dose of 5 to $10 \mu \mathrm{g}$. The animals die 5 to 8 days after injection, though the cause of death is still unknown (Bloch, $1950 \mathrm{~b}$ ). Kato and his associates have been conducting a long-term investigation to analyse the mechanism of toxic action of cord factor in mice (Kato et al., 1956) 
(Kato et al., $1959 \mathrm{a}, \mathrm{b}$ ) (Kato, 1966a, b). The tentative conclusion is that the inhibition of the succinate-neotetrazolium reductase system in mouse tissues by infection with virulent tubercle bacilli or by injection of cord factor is attributed to diminution of a dializable factor which would link the reduction of neotetrazolium with the electron transport chain, probably biochemical lesion being present between reduced eoenzyme $Q$ and and cytochrome c. Interesting enouth, heat-killed in vivo grown organisms were reported to posses a more marked inhibitory effect on the succinate oxidase and succinate-cytochrome $\mathrm{c}$ reductase system than those grown in vitro. Kato $(1966 \mathrm{c})$ isolated another toxic fraction of the same activity from the firmly bound lipids.

The similar line of investigation has been conducted for long years by Chaudhuri and Martin (1953), Martin et al. (1955), and Chaudhuri et al. (1963), though they were not particularly concerned with cord factor. Their first observation was that succinic dehydragenase activity of the guinea pig kidney was reduced by infection with virulent tubercle bacilli. This observation was recently explained that a defect was present in the electron-transport chain at the level of the flavoprotein-diaphorase system. A significantly high NADase activity of kidney homogenate has also been found in the infected group. This fact reminds us of the investigation of Bekierkunst and Artman (1962), Bekierkunst, Artman and Silman (1964), Windman, Artman and Bekierkunst (1965). As described before, their works on tissue metabolism in tuberculous infection started from the metabolic study of in vivo grown tubercule bacilli, and their critical observation was that NADase activity increased up to 2 to 3 folds in the tissue of infected mice.

On the other hand, Middlebrook, Coleman and Schaefer (1959) extracted a sulfolipid from moist living cells of virulent tubercle bacilli with petroleum ether containing a small amount of an aliphatic amine. This lipid has a property to fix neutral rad, suggesting to be a factor responsible for cord formation (Gangadharam, Cohn and Middlebrook, 1963). Further informations are yet unavailable concerning its biological properties.

\section{E. The Natural Course of Tuberculous Infection in Experimental Model}

Tuberculosis is a chronic infectious disease, in which the host-parasite relationship does not remain the same thoughout their entire course, but changes from one stage to another of the infection. The interaction between the host and tubercle bacilli creates a new immunologic and pathologic condition in the host body, and the new condition will in turn govern the subsequent behavior of the bacilli thus leading to the establishment of a modified host-parasite relationship. The evolution of infection will proceed repeating this process until a host-parasite equilibrium is brought about. Natural and acquired resistance, hypersensitivity, circulating antibodies, and others are all interfering with that process in a delicate fashion. In this sense, the immunology and the pathology can not be discussed separately in tuberculosis.

In spite of this complexity, however, microbiologists have been studying the general picture of tuberculous infection in the experimental model by following the fate of infecting tubercle bacilli mostly in mice and guinea pigs. It is their basic understanding that multiplication and survival of the bacilli in vivo as revealed by enumeration of viable counts of the tissue is a net result of such complicated interaction and competition between the host and the parasite. The investigation of tuberculous infection and 
immunity along this line has been conducted by Pierce, Dubos and Schaefer (1953), Mackaness, Smith and Wells (1954), Dubos (1954, 1955), Bloch and Segal (1955), Kanai and Yanagisawa (1955), McCune and Tompsett (1956), McCune, Tompsett and McDermott (1956), Youmans (1957), and many others. Regardless of some technical differences, they all reached the same fundamental observation that a small dose of virulent tubercle bacilli multiply to a great extent in the susceptible organs of the susceptible animals during the first 2 to 3 weeks. Then, they cease to multiply, being followed by some degree of decline of viable counts for the subsequent few weeks. Finally, the stage of bacillary persistence ensues maintaining nearly a constant viable count.

In their experiments, intravenous route of infection was employed, because this way can infect animals most uniformly. Recently, however, Larson and Wicht (1962) and Smith, Wiegeshaus, Navalkar and Grover (1966) have obtained quite the same observation as above in experimental airborne tuberculosis of mice and guinea pigs. Thus, the initial multiplication, the subsequent decline phase, and the final persistent period can be regarded as the natural course of tuberculous infection in the experimental model. And, this pattern is never contradictory to the actual situation of human tuberculous infection. A great majority of tuberculous infections in man is considered to remain as nonclinical cases taking the infectious process similar to the above. Only in some particular cases, the primary infection will develop continuously accompanying clinical signs until the host dies. Or, in some other instances, relapse may occur during the chronic phase because of the break of the once established host-parasite equilibrium. In order to understand the nature of resistance to tuberculosis, we can derive many suggestions from this pattern of tuberculous infection. In addition, it will be possible to see the nature of protection afforded by immunizing agents from a vaccine-modified infection course. For instance, almost all the authors referred to in this section have observed that the immunizing effect of living vaccines such as $\mathrm{BCG}$ and $\mathrm{H} 37 \mathrm{Ra}$ is related to partial or complete prevention of the initial high state of bacillary multiplication in nonimmunized controls. This fact was recently confirmed by Bjerkedal (1964) in his large-scale experiment. On the other hand, Kanai and Yanagisawa (1955) demonstrated a peculiar situation of tuberculous immunity by their reinfection experiment in guinea pigs. Infecting tubercle bacilli remained in the spleen maintaining constant viable counts. During this chronic phase of infection, the animals were reinfected intravenously with the streptomycinresistant variants of tubercle bacilli. Differential enumeration of spleen viable counts of both the primary and secondary challenge strain revealed that multiplication of the bacilli of the secondary infection was completely inhibited, whereas the bacilli of the primary infection still continued to survive showing the unchanged high level of viable counts. This observation is an evidence to prove that the mechanism of tuberculous immunity can operate to inhibit the bacillary multiplication due to the secondary infection, but it can not destroy the primary infection. In other words, the presence of living bacilli in the primary lesion will protect the individual from the consequence of massive new tuberculous infection. Nevertheless, tubercle bacilli in the primary lesion, even though they are in a resting condition, have a potentiality to initiate multiplication again when some environmental conditions are afforded. In this sense, the harvoring of resting tubercle bacilli in a primary lesion is a double-edged sword as well stated by Bloch (1954). A more detailed discussion on the nature of bacillary persistence will be discussed in the next section on the basis of several experimental observations. 


\section{F. The Nature of Persistence of Infecting Bacilli}

The persistence of viable forms of tubercle bacilli in the host tissue is a characteristic feature of the natural course of tuberculosis, particularly of the arrested phase of infection. Many experimental and clinical observations in the past revealed that such microbial persistence is established resisting to the defense mechanisms of the host and despite the efforts by chemotherapy to eliminate them (McDermott, 1958) (Smadel, 1963). This fact has therefore been attracting not only our academic interest from the immunological point of view, but also our practical concern from the clinical and epidemiological standpoints. In fact, as described in the preceding section, tubercle bacilli can persist in the mice and guinea pigs maintaining nearly a constant viarle count in the later period of infection. Needless to say, this stage of infection comes after acquired immunity is established firmly enough to inhibit the multiplication of infecting bacilli. In a sense, the phenomenon of bacillary persistence can be attributed to the limitation of acquired immunity, or to the host-parasite equilibrium. Then, a question is raised why this type of parasitism is brought about, and whether the equilibrium between the host and parasite is dynamic or static in nature. In other words, are the bacilli persisting in the balanced number between multiplication and destruction, or can they survive in a resting condition? In recent years, several authors have attempted experiments to examine which possibility is tenable. Rees and Hart (1961) analysed the equilibrium by following in parallel the viable and the total (stainable) bacillary populations in lung homogenates from mice with chronic tuberculosis.

The total counts from the lungs remained steady and were similar to the viable counts from day 60-138 of chronic infection. This result indicated that unless dead organisms were being removed from the lungs or their acid-fastness was being lost, the bacillary population was viable and not multiplying. When similar mice received a combined treatment with isoniazid and pyrazinamide, although the viable counts fell steeply throughout the treatment period, the total counts remained high, falling slowly after 3 weeks' treatment below the total counts of the untreated mice. These results indicate that a high proportion of the dead bacilli (killed by the treatment with isoniazid and pyrazinamide) were not removed from the lungs and retained their acid-fastness. It is concluded therefore that in chronic murine tuberculosis the bacilli are in a static or resting phase rather than in a dynamic equilibrium between multiplication and destruction.

With the same object in mind, Wallace (1961) conducted a different type of experiment. Actively growing and stationary phase cultures of tubercle bacilli were found to differ in their susceptibility to heating at $53 \mathrm{C}$. The difference was also demonstrable when the cultures were heated in the presence of tuberculous mouse lung. The heat resistance of the infecting bacilli in the lungs of chronically infected mice resembled that of stationary phase cultures. This indicates that the bacilli were in a resting state, and again supports that the host-parasite equilibrium in chronic tuberculous infection is a static one.

Kanai (1966a) also reached the same conclusion concerning the nature of host-parasite equilibrium by his particularly arranged biologic model of infection using a streptomycindependent strain of tubercle bacilli. A resting condition of tubercle bacilli was obtained in vitro after residual growth of the strain on the antibiotic-free Sauton medium. Then, infection experiments were conducted employing vaccines and challenge inocula prepared from the non-proliferating resting cells thus induced and confirmed in vitro. First, it was found that the mice and guinea pigs immunized with the resting vaccine were 
poorly protected against an intravenous challenge infection with virulent tubercle bacilli. However, when the same vaccine was used concurrently with supply of streptomycin to the host to permit its temporary multiplication, a strong immunity was induced. Further comparative studies on these two modes of vaccination, particularly regarding the relation between immunizing dose, extent of vaccine multiplication, and degree of protection, indicated that the main factor of viable vaccine responsible for immunity production is not the total amount of viable cells, but their performance of multiplication in the host. Secondly, reversing the process, when the resting bacilli were used as a challenge inoculum in preimmunized mice, it was found that the resting bacilli were not destroyed in those animals. From these observations, the author was led to an idea that resting tubercle bacilli do not stimulate the host in a manner to produce protection, and at the same time they are insensitive to preformed immunity, thus establishing an " indifferent" type of parasitism or a latent infection. In fact, the streptomycin-starved resting bacilli survived in the mouse spleen maintaining nearly constant viable counts for the period as long as at least 9 weeks. An additional observation was that antituberculous agents such as isoniazide and kanamycin were not effective in eliminating the resting bacilli in vivo, suggesting the possible presence of a delicate " host-parasitedrug relationship". This investigation indicated also that the processes which account for acquired immunity in tuberculosis do not kill tubercle bacilli, but only inhibit their multiplication. This limitation may be responsible for the fact that virulent tubercle bacilli do persist for years in persons who have overcome tuberculosis (McDermott, 1958).

A similar experimental model had been found in mouse corynebacteriosis by PierceChase, Fauve and Dubos (1964) and Fauve, Pierce-Chase and Dubos (1964). Their observations suggested that $C$. kutscheri can persist in vivo in an avirulent form which is resistant (or "indifferent" in the reviewer's words) to the defense mechanisms of the host. After all, in the chronic type of bacterial infection, it appears a common phenomenon that the defense mechanism which prevents multiplication of the virulent forms of the phathogen can not eradicate its resting or avirulent forms.

On the other hand, resistance to tuberculous infection has long been considered as "infection immunity", whose concept is that the resistance results from the persistence of viable forms of the homologous pathogen in the tissue of the host. Therefore, it might be stated that resistance to tuberculosis is established at the cost of potential danger that latent and arrested infection could be reactivated into apparent diseases. This might be another paradoxical feature of tuberculous infection.

Much earlier than those investigations described above, McCune, Tompsett and McDermott (1956) were interested in the problem of persistence of tubercle bacilli in association with chemotherapy. They demonstrated that the bacilli in the chronic stage of infection could escape in some way from the effects of chemotherapeutic agents, and they could not be eradicated. This phenomenon was observed regardless of the drug sensitivity of the bacilli. According to their most recent studies (McCune et al., 1966) (McCune, Feldman and McDermott, 1966), it was found that infecting tubercle bacilli did "vanish" during a prolonged survival in mouse tissues, being undetected by any microbiological technique, but were not eradicated. They used the expression of "sterile state" for such persisting tubercle bacilli. And, a similar state was most readily produced by administration of nicotinamide derivatives, pyrazinamide, and isoniazide. Cortison administration in a large amount could speed up the process to that state.

Then, additional questions will be raised in what morphological, biochemical, and immunological forms infecting tubercle bacilli are persisting in the stage of host-parasite 
equilibrium. This must be a problem of fundamental importance in association with vaccination and chemotherapy, particularly in the present era of tuberculosis evolution.

In connection with the mechanisms of bacterial persistence in vivo, there has been a speculation that the bacilli may survive in the host tissue by altering their morphological properties, particularly the surface structure (McDermott, 1958) (McDermott, 1962) (Smadel, 1963). As described previously in the section of phagocytosis, a cell wall-lytic agent, lysozyme, is present in cytoplasmic granules of phagocytic cells, and it is discharged into the phagocytic vacuole in which the ingested bacteria are located. Some authors (Myrvic and Weiser, 1951) (Myrvik, Weiser and Agar, 1953) (Oshima, Myrvik and Leake, 1961) have suggested its possible playing an important role in resistance to tuberculosis and also in acquired resistance to the disease. Probably due to the high content of the surface lipids of the cell wall (Kotani et al., 1959) (Surdy and Hartsell, 1963) and because of the slow rate of growth, tubercle bacilli are not so sensitive to the lytic action of lysozyme as other species of bacteria. However, Thacore and Willett (1963) succeeded in producing osmotically fragile spheroplasts of $M$. tuberculosis (H37Ra) by growth in a medium containing lysozyme and EDTA. These spherical forms were establized in the presence of sucrose and $\mathrm{Mg}^{*}$. In their more recent investigation (Thacore and Willett, 1966), it was demonstrated by phase-contrast microscopic observation and electromicroscopy that spheroplasts or L forms of $M$. tuberculosis can be produced during phagocytosis by the tissue culture cells placed in the environment containing an elevated concentration of lysozyme. In connection with this, it might be interesting to see that Hatten and Sulkin $(1966 \mathrm{a}, \mathrm{b})$ were also successful in demonstrating that $\mathrm{L}$ forms can be recovered from tissue culture cells infected with Brucella abortus, which is an intracellular parasite capable of causing chronic and persisting infection. As a matter of fact, Mattman et al. (1960) had shown that L variation of mycobacteria was produced by growing the bacilli in an environment lacking the essential nutrients for maintenance of acid-fastness. This information is in accordance with the finding of Thacore and Willett (1963) that the spheroplasts of tubercle bacilli are nonacid-fast or stained very faintly by Ziehl-Neelsen's stain. The recent observation of Nyka (1963) should also be cited here; his new staining method could reveal tubercle bacilli in a great number in tissues in which carbol-fuchsin showed few or none. Much earlier than these investigations, Consden and Glynn (1955) and Consden and Howard (1957) reported that they could detect diaminopimelic acid, a cell wall component, in a fairly large amount from tuberculous lesions in the lungs. In view of these informations reviewed above, it will not be very difficult to speculate that tubercle bacilli may exist in vivo, at least in some cases, taking a form defective in their cell wall structure, namely spheroplasts or $\mathrm{L}$ forms. Although we have no direct evidence at this moment to prove that such altered forms of infecting bacilli are resistant to the mechanism of acquired immunity and chemotherapy, such possibility will not be so far from real. In fact, Guze and Kalmanson (1964) have presented a suggestive example of bacterial persistence in "protoplasts" in rats apparently cured of pyelonephritis. They could recover a larger number of causative bacilli using the medium containing $0.3 \mathrm{M}$ sucrose than by the conventional medium lacking sucrose.

Further discussion of in vivo persisting tubercle bacilli should be made concerning their metabolic functions, particularly respiration. As we have already discussed, the in vivo grown tubercle bacilli are extremely poor in the substrate respose of oxygen consumption in comparison with the corresponding suspensions of the same strain grown in vitro (Segal and Bloch, 1956). This phemenon was then explained by Artman and 
Bekierkunst (1963) as indicating that NADase of host-origin is present on the surface of the bacilli as a metabolic inhibitor. Besides, there are some gocd reasons to believe that tuberculous lesions are more or less anaerobic. Such an environment would be unfavorable for the multiplication of tubercle bacilli which have been regarded as a strict aerobe (Youmans, 1957) (Middlebrook, 1965). In recent years, however, the presence of functional glycolytic pathways was demonstrated in tubercle bacilli by Bastarrachea, Anderson and Goldman (1961), and Indira and Ramakrishnan (1963). This might suggest a possibility that tubercle bacilli can conduct metabolism, even in the environment of a low oxygen tension, to maintain their viability, if not to multiply.

In the experiments of Kanai (1966a), as described before, a streptomycin-dependent strain of tubercle bacilli could survive without multiplication in vitro and in vivo in the abscence of streptomycin. Although there is no information available concerning the metabolism of this type of resting tubercle bacilli, some analcgy will be asked to the findings in E. coli. Engelberg and Artman (1961) observed the effect of growth in limiting amounts of streptomycin on respiration and fermentation of a streptomycindependent strain of $E$. coli. Their finding was that the growth in such an environment resulted in elevated glycolysis, decreased respiration, and loss of cytochrome oxydase activity. It appears that the residual respiration was performed by cytochrome $b$ and flavine. More recently, Bragg and Polglase (1964) reported that lactic acid was formed by a streptomycin-dependent strain of $E$. coli in the condition of antibiotic depletion, perhaps relating to a deficiency in the electron-transport system. If the same situation was true in the case of the streptomycin-dependent strain of tubercle bacilli as used by Kanai (1966a), it would follow that the glycolytic pathway may be predominantly operative to sustain their survival in vivo in the abscence of streptomycin, thus again presenting a biochemical model regarding the persistence of tubercle bacilli. A more detailed discussion on this matter has been made in the section of the virulence of tubercle bacilli.

\section{IMMUNity (PROTECTION)}

\section{A. Problems of Methodology for Evaluation of Protective Antigens}

In spite of a massive accumulation of literature concerning the mechanisms of antitubercular immunity few of the basic problems in this field have been resolved completely. One of the factors which have been hindering our understanding of fundamental mechamisms of antitubercular immunity is certainly the absence of methods for measuring accurately many of the phenomena investigated. As stated before, tuberculous infection is a chronic infectious disease, in which the host-parasite relationship dces not remain unaltered throughout the entire course of infection. This suggests that a single method to measure the immunity in one phase of infection, even if it is sensitive, accurate, and valid, will not be satisfactory for other phases of infection. In other words, one method can make clear one aspect of tuberculous immunity, but not other aspects. If so, we need more than one methods for understanding the total picture of tuberculous immunity. However, little attention has ever been paid to this point. Therefore, before entering into discussion on protective antigens and the mechanisms of acquired immunity, some considerations will be made regarding the problems of methodology.

In studies of immunity, laboratory animals are usually vaccinated with either living bacteria or some fractions thereof. Later, these animals, as well as non-vaccinated 
control animals, are challenged with a dose of virulent mycobacteria. The increase in resistance is then measured by comparing the vaccinated animals with the control animals, either by noting the survival times or by killing and examining sampled animals with appropriate time-intervals. There is still considerable disagreement about the relative suitability of animal species, the dose and route of immunization and challenge, and various indices of protection. Each point will be discussed below.

a) Maintenance of virulence of challenge strain.

It is essential for animal experiments to maintain the virulence of the challenge strain at a constant level. Fortunately, a long year experience of several authors (Steenken, 1946) (Youmans and Youmans, 1957) (Karlson, 1965) demonstrated that virulence of standard stock strains such as $\mathrm{H} 37 \mathrm{Rv}$ is quite stable as long as they are subcultured on synthetic liquid medium (for instance, Proskauer and Beck medium). In contrast, the virulence is rapidly reduced by frequent subcultures on glycerol egg media, particularly in acidic condition (Steenken, 1946) (Kanai, 1966 b). In the case of subculture on synthetic liquid medium, it appears important to keep pellicle growth thin and even, and to conduct transfer of pellicle with suitable time-intervals before the medium turns acidic.

b) Preparation of infection inoculum.

Even though the cultures of virulent tubercle bacilli on synthetic liquid medium are desirable for challenge infection from the reason stated above, finely dispersed bacillary suspensions must be prepared from the pellicle growth for a challenge incculum to animals. Many workers make such suspensions by grinding the pellicle in a mortar or in a round flask containing beads of various kinds. But, other people use a dispersed culture in Tween-albumin medium transferred from a growth on systhetic liquid medium. In whatever case, however, it will be impossible to expect that the suspensions thus prepared consist of perfectly dispersed single bacillary cells. Therefore, Smith et al. (1966) for instance employed a combined procedure as follows. They maintain the stock culture of H37Rv by subculture on Sauton medium. The young pellicle on this medium is transferred to $5 \mathrm{ml}$ of Dubos broth (Difco) and is inoculated into $10 \mathrm{ml}$ of Dubos broth in prescription bottles. After 7 days of incubation at $37 \mathrm{C}$, the contents of several bottles are homogenized and filtered through a membrane of $5-\mu$ pore size to remove clumps of bacilli. The concentration is adjusted nepherometrically. The bacillary suspension thus prepared is satisfactory for their airborne infection experiment in guinea pigs.

Viable units of the challenge suspension must be examined immediately before use. In addition, physiologic conditions of the bacilli at the time will be another factor responsible for the outcome of infection. However, little is known as to this point.

c) Dose and route of infection, and eraluation of raccine effect.

These three matters can not be discussed separately. Roughly speaking, immunization and challenge experiments can be divided into two types. They are fundamentally different in a very important point.

In the case of high dose infection ( $1 \mathrm{mg}$ for instance), which is usually conducted intravenously in mice, the immunizing effect of vaccines is established by comparison of survival time between vaccinated and unvaccinated groups. This method allows us to make an objective numerical expression of protective effect with statistical treatment. The distribution pattern of survival times is unimodal in such a high dose infection, the mean of the distribution being used as an expression of the relative resistance. However, 
as reported by Youmans and Youmans (1957) and Terai and Nagasuga (1962), the unimodal curve changes into a bi-model curve when the group of mice has been vaccinated with BCG or H37Ra and then infected with a high dose. The second phase can be considered as a result of immunizing effect of the living vaccine. Such bi-model distribution curve of the survival time could also be obtained by Bloch (1954) when he infected intravenously a large number of mice using a lesser amount of virulent tubercle bacilli without previous immunization. A plausible explanation given by him was that in the course of infection the mice had acquired a degree of immunity protecting them for an extended period of time from the effects of infection. Therefore, it must be possible that challenge with a small dose of tubercle bacilli sometimes fails to reveal the true vaccination effect by masking it behind the strong immunity induced by challenge per se. In view of this fact, many workers have been considering intravenous challenge with a high dose of virulent tubercle bacilli as a better way to evaluate vaccination effect. In fact, this type of challenge infection can reveal definitely the immunizing effect of BCG which is the most reliable vaccine ever found.

However, some other workers hesitate to employ this method for the reason that it is too artificial and so different from the actual situation in man. For instance, Smith et al. (1966) used airborne infection instead of intravenous infection, a minimum dose of infection instead of a high dose, guinea pigs instead of mice in which delayed sensitivity is a moot subject, and enumeration of tissue viable counts for evaluation of vaccine effect instead of survival time.

In the case of smaller dose infection, we can use two different methods for evaluation of vaccine effect. First, animals are killed at suitable time-intervals, being sampled from both vaccinated and control groups, and a visual estimation is made of the relative amount of gross and microscopic disease found in the organs and tissues of the two groups. The observations are sometimes subjective, and may be worthy of recording only as a side information of other data. A more reliable evaluation will be made by counting and comparing the number of tubercle bacilli found in organs of the infected normal and immunized animals. Since the work of Pierce, Dubos and Schaefer (1953), this method has become common among tuberculous immunologists, despite the extreme laboriousness in practice. An advantage of this experimental procedure is that resistance to infection caused by vaccination can be grasped as an antibacterial immunity. Besides, it developed a new concept in immunology, namely the problem of " persister" in chronic infection. This subject has already been discussed before.

\section{d) Route of immunization.}

BCG-vaccination in man is usually practised intracutaneously with successful results in sensitization and protection. The same situation was recently observed in guinea pigs, which were vaccinated intracutaneously with BCG and then challenged by airborne infection with virulent tubercle bacilli (Smith et al., 1966). However, the same authors also found that mice vaccinated subcutaneously with BCG were not protected against airborne infection at any intervals between 2 and 19 weeks. On the other hand, guinea pigs vaccinated and challenged in the same conditions were protected as judged by counts of viable bacilli in the tissues 3 weeks after infection. More peculiar is the report of Ribi, Larson, et al. (1966) who proved the protective immunogenicity of cell wall fraction of tubercle bacilli only when mice had been vaccinated intravenously or by aerosol and then challenge by airborne infection. These observations are suggesting that the route of immunization is also an influential factor upon the effectiveness of vaccina- 
tion, and that local immunity might be associated in some instances. In fact, Middlebrook (1961) demonstrated that infection with as few as 10 viable units of one BCG strain by inhalation sufficed to provide as much immunity as $1,000,000$ bacterial cells of the same strain introduced by the cutaneous route in guinea pigs.

e) Experimental animals.

As far as tuberculous infection is dealt with as a host-parasite relationship, choice of experimental animals is of vital importance. Not only animal species, but also strain, sex, age, housing condition, and nutrition are also factors responsible more or less for the outcome of experiments. However, these problems would cover an extensive space of paper and they will be placed outside of the scope of the present review.

Mention will be made only about the recent interest in the use of germ-free animals. Miyagawa and Kishimoto (1962) has obtained a very limited experience of tuberculous infection in bacteria-free animals. More recently, Hobby et al. (1966) and Huempfner and Deuschle (1966) have reported a more extensive and systematic study on experimental tuberculous in germ-free mice in comparison with that in conventional mice. Huemphner and Deutschel pursued the course of infection by the microbial enumeration technique, but Hobby et al. compared the distribution of survival times between both mouse groups. Though infections were more uniform in the group of germ-free mice, no fundamental difference was oberved between them.

\section{B. Protective Antigens}

a) Living vaccine.

There is no longer any doubt that BCG is the most reliable antitubercular vaccine ever found. The effectiveness has been confirmed by both experimental investigations and epidemiological surveys for many years. Unlike various kinds of nonliving vaccines which are usually protective only in the hands of limited investigators, BCG has been proved effective by the majority of investigators, including Cohn, Davis and Middlebrook (1958), Shimoide (1960), and Smith et al. (1966) who studied on the problem by experimental airborne challenge infection. None the less, there is as yet no agreement concerning the essential properties of living vaccine responsible for induction of acquired immunity in experimental animals and in man. Does the effectiveness of living vaccine depend upon bacterial survival or multiplication in the host? Are there qualitative differences between living and nonliving vaccines in their mode of induction of acquired immunity? These questions are not yet answered satisfactorily.

Bloch (1954) has insisted that the effectiveness of living vaccine depends upon bacterial survival rather than on bacterial multiplication. This idea was derived from his two observations that $\mathrm{H} 37 \mathrm{Ra}$ strain, which can not multiply in mice, was as effective as BCG vaccine capable of multipling in that host, and that the degree of protection afforded by BCG vaccination under isoniazid administration was the same as with multiplying $B C G$ vaccine.

The evidence that H37Ra bacilli do not multiply in mice had been presented by Pierce, Dubos and Schaefer (1953), and was later confirmed by Sever and Youmans (1957 b). However, Mackaness, Smith and Wells (1954) noted an appreciable increase in the number of viable units of the same strain in the spleen of mice. Kanai, Katsuyama and Yanagisawa (1955) also found in guinea pigs that H37Ra organisms could multiply in the spleen to some extent. Making this problem more conflicting, Sever and Youmans (1957 b) observed that BCG, RIRv, and H37Ra were quite the same in that they did 
not multiply in mice, but the number of viable bacilli decreased repidly in the liver and slowly in the spleen. On the other hand, Jesperson and Bentzon (1964 a, b), who studied on the relative immunogenicity of four strains of $\mathrm{BCG}$ in red mice, found that the more virulent for hamsters, the BCG strain was the more immunogenic it was in red mice. Peculiar enough, some of the BCG strains they tested were virulent enough to kill hamsters.

Larson and Wicht (1964) demonstrated that H37Ra organisms, when injected into mice intravenously or by aerosol, could multiply in the lungs and spleen. Then, they studied on the effect of vaccine (H37Ra) multiplication on the degree of protection afforded, by controlling vaccine multiplication with isonizaid and pirazinamide. They reached a conclusion that there is a roughly proportional relation between vaccine multiplication and resulting immunity. Thus, it appears that the problem is not yet settled as far as H37Ra strain is used as live vaccine.

Kanai (1966 a) investigated the relation between vaccine multiplication and resulting protection using a streptomycin-dependent strain of tutercle bacilli. An adantage of the use of this strain was that a nonmultiplying (resting) condition could be produced in vitro when the strain finished residual growth after being transferred on antibiotic-free Sauton medium. The antibiotic-starved bacilli were found to survive both in vitro and in vivo for a prolonged pericd. Based upon this fact, vaccination and challenge experiments were conducted in mice and guinea pigs. The animals immunized with the resting vaccine were poorly protected from fatal infection with virulent tubercle bacilli. However, when the same vaccine was used concurrently with supply of streptomycin to the host to permit its temporary multiplication, a strong immunity was induced. Further comparative studies on these two modes of vaccination, particularly concerning the relation between immunizing dose, extent of vaccine multiplication, and degree of protection, indicated that the main factor of viable vaccine for immunity production is not the total amount of viable cells, but their performance of multiplication in the host. A similar situation was found by Kishimoto, Akiyama and Ushita (1964) in an experimental mouse infection with Salmonella enteritidis. They used a streptomycin-dependent strain as vaccine and the results indicated that multiplication of the vaccine in the host was a factor responsible for induction of protection.

These observations may suggest that a protective antigen or antigens could be elaborated as a metabolite only while live vaccine is multiplying in the host. However, this idea conflicts with the fact that some degree of protection can be obtained by killed vaccine, if not so remarkable as that conferred by live vaccine. Then, we are led to a question whether or not the immune mechanisms of live vaccine are the same as those of killed vaccine. Even though the net result, as we can measure experimentally, of protective mechanisms could be the same, there would be still a possibility that the intermediate process to immunity production is different ketween the living and nonliving vaccines. Despite the graveness of this problem, little attention has keen paid to it hitherto. However, some light was recently shed on this problem from the investigation of Ushiba et al. (1966) on experimental typhoid, in which only live vaccine conferred solid immunity, whereas killed vaccines did not. They demonstrated that killed vaccines of an S-type virulent strain of Salmonella enteritidis produce the "clearance" factor in the sera of rabbits. It was identified as $\mathrm{O}$ agglutinin characterized as a class of macroglobulin with a sedimentation coefficient of $12.7 \mathrm{~S}$. In the early stages of an intraperitoneal infection with virulent organisms, a marked "clearance" phenomenon was observed in the peritoneal cavity of mice immunized with the S-type killed vaccine. 
And, a macroglobulin, similar to that identified in the rabbit serum, was extracted with urea from the cells of mice immunized with the S-type killed vaccine, but not from mice immunized with a live vaccine ( $R$-type mutant), although the latter vaccine was very effective in producing a solid immunity against typhoid disease. These observations. are certainly suggesting that live and killed vaccines are different qualitatively in their immunizing effect. At least in experimental typhoid disease as a model of infection due to intracellular parasite, it would be quite likely that "clearance", or phagccytic activities, could be enhanced by humoral factors (antibodies) and the intracellular inhibitcn of ingested bacilli would occur under the protective mechanisms afforded by live vaccine (cellular immunity). This type of experiment has not yet been reported regarding tuberculous infection. However, it was established by many workers that the mechanisms of protection induced by BCG or H37Ra strain is to inhibit the initial multiplication of the challenge strain of virulent tubercle bacilli. Bjerkedal (1964) recently confirmed this fact in his large scaled experiment. On the other hand, Bouvier and Böhme (1961) observed that killed BCG vaccine could stimulate the reticulcendothelial system to clear ingested carbon particles from circulation, though the vaccine would not be protective.

Thus, the immunity produced by live vaccine will be called as "bacteriostatic immunity". However, Robson, Smith and Thomas (1960) and Robson and Smith (1961) followed the fate of a virulent challedge strain by both total (stained) counts and culturable counts, and found that BCG vaccination can modify only culturable counts, not affecting total counts. This appears indicating that the immunity due to live vaccine is sometimes bactericidal, or a "grow to death" phenomenon of the challenge strain occurs in the immunized animals. Youmans (1967) has observed that when H37Ra strain was injected into animals previously immunized with $\mathrm{BCG}$, the bactericidal prccess was noted in the lungs and spleen. However, this was not the case when virulent tubercle bacilli (H37Rv) were used as the challenge strain, and the growth-inhibited bacilli continued to survive without destruction. Therefore, whether acquired immunity produced by living vaccine functions as "bacteriostatic" or "bactericidal" may depend upon the virulence of the challenge strain.

\section{b) Nonliving vaccines.}

Unlike the case of vaccination with living vaccine, the immunizing effect of nonliving vaccines is rather irregular and appears to depend upon as yet ill-defined factors concerning both the vaccines and the mode of challenge. This situation made Smith et al. (1966) state that every product of the tubercle bacillus has been shown to be protective in the hands at least one investigator. The extensive reviews of Crowle (1958) and Weiss (1959) have summarized almost all the investigations of antituberculous nonliving vaccines in the past. However, it will be practically impossible to evaluate the relative immunogenicity of those antigens cited in the reviews. Because, there is little common basis for comparison among them with regard to definition and criteria of protection, control vaccines of known potency employed, fractionation techniques of immunogenic materials, conditions of experimental animals, and so on. Space limitation does not allow to repeat such extensive surveys on killed vaccines or their fraction vaccines. Therefore, only the recent works of theoretical interest will be reviewed here.

Theoretically speaking, constituents of the tubercle bacillus will be divided into four categories; immunogenic (protective) antigens, nonimmunogenic substances having adjuvant effect on protective antigens, immunologically inert substances, and resistancelowering (or infection-enhancing) substances. The basic principle for preparation of 
nonliving vaccines must be that the first two are to be retained and the latter two are to be removed off. In fact, the presence of infection promoting factors in mycobacteria has been reported by Dubos and Schaedler (1957), and Smith (Smith, D. W., personal communication), although they still remain as an ill-defined material. As for the presence of substances with adjuvant activity in mycobacteria there is no more question, as evidenced by the example of Freund complete adjuvant which is commonly used for strong sensitization of animals. White et al. (1958), and Tanaka (1966) demonstrated that wax D fraction, a macromolecular peptidoglycolipid of $M$. tuberculosis is a principal agent of adjuvant activity.

In practice, however, the basic principle as above has not been adequately applied to the investigation or to preparation of nonliving vaccines, probably due to technical difficulties and laboriousness.

c) Immunogenicity of killed whole cell vaccines.

For a long time, various attempts have been made to kill tubercle bacilli without destroying their immunizing constituents for the purpose of preparing effective killed vaccines. However, many of them were unrewarding and none was brought into a wide practical use in man. Thus, efforts were still made recently in this direction. For instance, Nishihara et al. (1963) studied on the immunogenicity of cobalt-60 irradiated tubercle bacilli $(\mathrm{H} 37 \mathrm{Rv})$ in mice. Evaluation of protection was made by per cent survivals of the vaccinated animals after intravenous challenge with a fairly high dose of H37Rv tubercle bacilli. They concluded that four doses of $0.1 \mathrm{mg}$ or a single $1.6 \mathrm{mg}$ dose with adjuvant gave protection equivalent to that resulting from vaccination with living BCG. A careful survey of their data, however, indicates that the immunogenicity of the cobalt-60 irradiated vaccine was equivalent to that of BCG only when compared in the later stage of infection, at least 100 days after infection. And, when evaluated by percentage of 30 day survivals, BCG was more effective than the cobalt- 60 irradiated vaccine. This type of protection would be often observed in the case of killed vaccine, suggesting that, even though the introduction of such killed vaccine does not result per se in the production of a high degree of immunity, the slow growth of virulent tubercle bacilli used for challenge might permit the anamnestic production of a high degree of immunity before the infection has time to become fatal. In other words, the immunity purely due to vaccination can not be observed because of the addition of "infection immunity".

On the other hand, Costello and Dubos (1965) studied on the immunogenicity in mice of H37Rv and BCG organisms killed with ethylene oxide. The killed mycobacterial cells were found to show minimal disorganization of cellular structure. Evaluation of protection was made by three different criteria: (1) survival time of vaccinated and challenged animals, (2) modification of the fate of challenge strain in the host, (3) spread of challenge organisms from the lung to the spleen. Protection resulted in a two to three fold increase in survival time, being always equal to or better than that given by BCG vaccination. The vaccine was also effective as judged by the other two criteria. Interesting enough, when the vaccine was further treated by heat, the immunogenicity was lessened or abolished. In addition, it is worthy to note that the vaccine was effective in such a small dose as $30 \mu \mathrm{g}$. This work is to be confirmed by independent investigations of other workers in future.

\section{d) Immunogenicity of the structural elements of the tubercle bacillus.}

One of the recent advances in tuberculous immunology was obtained regarding the 
relationship of the structural elements of the tubercle bacillus to their immunological properties. The idea to this line of investigation must have occurred when Salton and Horne (1951) first described a method of separation of bacterial cells into major morphological elements. Roughly speaking, the bacillary body of the tubercle bacillus can be separated by physical procedure into 3 structural components; cell wall fraction, particulate fraction and soluble fraction. The particulate fraction represents internal structures including fragmented cytoplasmic membranes, nuclear equivalents, ribosomes, mesosomes and others. The soluble fraction may consist of protoplasm diluted with the medium used at the time of cell disruption and other solubilized components from solid structures.

For the past ten years, the immunological properties of those bacillary structures have been studied with tenecious efforts by Youmans and his associates on one hand, and by Ribi and his associates on the other hand, sometimes causing much controversy concerning the location of protective immunogenicity. In addition to these, some discrete informations were also presented from the workers in Japan, again causing yet unsettled arguments. However, according to the present reviewer, the discrepancy among their results and interpretations is never of a fundamental nature, but it is due to the technical problems for evaluation, and also to the different aspects of protection with which they are concerned.

e) Cell walls as an immunizing agent.

Ribi et al. (1958) were the first who worked on the immunological properties of cell walls separated from viable mycobacteria (M. butyricum, H37Ra and BCG). The bacilli suspended in $0.5 \%$ Tween 80 solution were shaken with minute glass beads in a Mickle apparantus. After repeated washing of the disrupted material with the Tween solution at $2,000 \mathrm{~g} \times 60$ minute centrifugation, cell walls were obtaind as a translucent upper layer of the sediment. The cell wall fraction was found to be biologically active; lesions were produced in the rabbit skin by intradermal injection, and at the same time the animals were conferred with delayed sensitivity. On the other hand, internal protoplasm was lacking in such properties. Two years later, Kanai, Youmans and Youmans (1960) substantiated their observations and demonstrated further that trypsin, pepsin, and ribonuclease do not affect the allergenicity of cell wall preparations, but extraction with alkaline-ethanol destroys the activity, presumably by extracting lipoproteins contained in the cell wall structure.

However, yields of cell walls obtained by the above procedure were so small that biological analyses remained limited. In order to overcome this difficulty, Ribi et al. (1959) devised a method which employed a pressure cell with a cooled orifice for rupture of large quantities of organisms. Unlike the previous method by which the bacilli were cracked at one end of the rod, the pressure cell apparatus could split the rod into two large parts perpendicular to the long axes. By differential centrifugation of the effluent, cell walls and protoplasm were obtained in good yield with a high degree of purity, for instance $60 \mathrm{mg}$ cell walls per $1 \mathrm{mg}$ of the starting whole cells. With such good yield of the material, observations of the pathogenicity and allergenicity of cell walls were expanded by Larson et al. (1961). They demonstrated that $1 \mu \mathrm{g}$ of cell walls of $M$. butyricum and $M$. tuberculosis injected intradermally into normal rabbits produced a lesion. Rabbits vaccinated with $2.5 \mu \mathrm{g}$ of $M$. butyricum or $10 \mu \mathrm{g}$ of $M$. tuberculosis cell walls developed hypersensitivity to cell walls, protoplasm and in the case of tubercle bacilli, to OT and PPD as well. Delayed reactions elicited by protoplasm 
were similar to those given by OT and PPD. Reactions induced by cell walls were far more intense and persistent. Protoplasm was inactive in producing lesions and in inducing delayed sensitivity. Furthermore, they obtained an interesting finding that rabbits sensitized with cell walls of $M$. tuberculosis or $M$. butyricum reacted in a specific manner when delayed reactions were elicited with heterologous or homologous protoplasm, but they did not respond specifically to those cell wall fractions. These original studies have recently been extended to include both rabbits and guinea pigs as hosts, and $M$. tuburculosis, M. balnei and Group I, II and III unclassified acid-fast bacilli as sensitizing materials and protoplasms from these organisms as provoking agents (Larson and Ribi, 1966). The results indicated that sensitized guinea pigs responded to smaller amounts of homologous protoplasm than sensitized rabbits. Sensitized rabbits or guinea pigs reacted to smaller amounts of homologous than of heterologous protoplasm. These findings suggest that the protoplasm from acid-fast bacilli may be used for the specific detection of infection in man and animals.

As for the protective immunogenicity of cell walls, however, they had been unsuccessful in demonstrating it by the conventional method until 1963. Here again, some improvement of experimental techniques was to be made for furthering the investigation. Suggestion came then from Smith (1962) who reported that BCG organismus disrupted in oil were highly immunogenic. Adopting this method, Larson et al. (1963) separated crude cell walls from BCG organisms disrupted in mineral oil by the Sorvall refrigerated cell fractionator set at $43,000 \mathrm{lb}$. $/ \mathrm{in}^{2}$ at 5 to $10 \mathrm{C}$. This oil-disrupted material was then suspended in saline containing $0.02 \%$ Tween 80 , and sterilized at $65 \mathrm{C}$ for 30 minutes. The corresponding material, which was first disrupted in water instead of mineral oil and then treated in the same way as above, was prepared. In addition, the original water-washed unbroken cells were also used for mouse protection test as the third sample. Each of these materials was given intravenously to 20 mice, which were then challenged by airborne infection with $\mathrm{H} 37 \mathrm{Rv}$ tubercle bacilli 20 days later. Evaluation of protection was made by visual counting of tubercles in the lungs and also by viable counts of the spleen. The results indicated that only oil-disrupted products (mostly cell walls) were protective in a small dose of $200 \mu \mathrm{g}$ and the other two samples were not.

At this time, it must be noted that such a mouse protection was obtained in the very particular experimental conditions; presence of oil in the immunizing agent, intravenous route of vaccination, and airborne challenge. Though "disruption in oil" appears good to prepare protective antigens, it would make the subsequent procedures difficult to separate cell walls from other structural elements in a possible pure state. Besides, there was still a possibility that what was needed for the immunogenicity of cell walls, if any, was not "disruption in oil" but "oil-coating of cell walls". These questions were answered by Ribi, Larson et al. (1966). They found that cell walls obtained from BCG disrupted in water were highly protective by intravenous vaccination if they were prepared in an oil paste and then suspended in Tween-saline solution. Thus, "disruption in oil" is not an essential procedure for preparation of immunogenic cell walls. Oil-coating is the requisite for that. In addition, they demonstrated that protoplasm and killed whole cells of BCG were not protective, even with the aid of oil adjuvant. These observations led the authors to an idea that the protective antigen might be an inner component of the cell wall, exposed when the cell was disrupted and activated by oil. In fact, the median number of virulent organisms in the lungs of mice immunized with a few hundred micrograms of oil-treated cell walls was 3 to 4 logs lower than in unvaccinated control mice. A smaller dose of viable BCG standard 
vaccine reduced the lung count 1 to 2 logs below the controls.

Ribi, Brehmer and Milner (1966) examined then the immunological specificity of the oil-coated mycobacterial cell walls in relation to those of $S$. typhimurium, Br. abortus, and L. monocytogenes. First, it was shown that the oil-treatment of cell walls does not increase their capacity to stimulate nonspecific resistance to infection in mice. Secondly, coating with oil of BCG cell walls was found not to affect the specificity of reactions conditioned by cell walls in this and other systems. Thirdly, when the interval between vaccination and challenge was as short as 24 hours, mice were protected against heavy intravenous challenge with $M$. tuberculosis principally by nonspecific factors ; after a 30 day interval, protection appeared to depend upon the mixture of specific and nonspecific effects.

Keeping pace with the above experiments, Ribi, Anacker et al. (1966) further extended the observations of adjuvant activities of liquid mineral oil and other related hydrocarbons for cell wall immunogenicity. A peculiar finding was that oil-coated cell walls suspended in saline solution with the aid of emulifier were not potentiated in their tuberculin-sensitizing activity in guinea pigs. This observation appears contradictory, because a survey of literature (Freund, 1947) (Rist, 1951) shows that liquid mineral oil can enhance the sensitizing activity of killed whole cells of the tubercle bacillus. Probably, a delicate situation might be prevailing concerning the adjuvant activities of mineral oil for the immunogenicity and allergenicity of cell walls in mice and guinea pigs. Then, it was also found that a synthetic hydrocarbon, 7-n-hexyloctadecane, can be used satisfactorily for the present purpose, and that vegetable oils and kerosene are not active in this respect.

Finally, duration of the vaccination effect with oil-coated cell walls is worthy of mentioning (personal communication from Ribi). Mice were vaccinated with either viable BCG or oil-coated cell walls suspended in Tween-saline, being followed by airborne challenge with $\mathrm{H} 37 \mathrm{Rv}$ strain. Visual examination of the lungs indicated that most lungs of mice vaccinated with BCG were free of lesions when sacrificed 30 days after challenge, but 18 out of 20 had lesions 120 days after challenge. In contrast, only 2 out of 20 which had been vaccinated with oil-coated cell walls had lesions at this time.

As already discussed herein in connection with cobalt-60 irradiated vaccine, the effectiveness of killed vaccines is sometimes superior to that of viable vaccines when compared at a later period of infection. On the other hand, protection produced by BCG vaccination is sometimes broken in the later stage of infection, at least in experimental studies (personal communication from Smith, D. W.). These informations appear again suggesting that protection due to viable vaccines and that due to killed vaccines are not the same in nature.

After all, it seems clear at least in mice that the immunogenicity of heat-killed nonliving vaccine is located in the cell wall structure. However, questions are still raised why added oil is needed for the immunogenicity of cell walls, why they must be intravenously administered for effective vaccination, and why these peculiar conditions are not required for viable vaccines. The recent reviewer is thinking that the minute granulomatous lesions caused by oil-coated cell walls in the lungs may be the site of a strong local immunity, where virulent tubercle bacilli inhaled would be most effectively destroyed.

While cell wall investigation was progressing in Ribi's laboratory, similar efforts have been done in some other places, though in a much smaller scale. Higashikawa (1960) 
obtained a cell wall preparation from viable BCG organisms grown on Sauton medium. Disruption of cells was done by magnetostriction oscillator and they were purified by washing with buffer, trypsin digestion, and again by washing with distilled water. Electron-microscopy revealed that cell walls thus obtained were rather fragmented. He studied then the immunological properties of this fraction and found that it was active in sensitizing guinea pigs to tuberculin, in producing lesions in the rabbit skin and lungs, and also in conferring resistance to infection in mice. It must be mentioned here that the cell wall fraction was used for vaccination after being heated at $65 \mathrm{C}$ for one hour, just as in the experiments of Ribi and his associates. This procedure was probably to kill contaminating viable cells in the cell wall fraction. Actually, it is extremely difficult to remove perfectly such contaminating viable whole cells only by differential centrifugation.

Then, Kanai and Youmans (1960) prepared unheated pure cell walls of H37Ra in a more complicated way. First, the viable whole cells of H37Ra were disrupted by a pressure system to obtain a crude cell wall fraction. Then, the fraction was further treated by Waring blender with minute glass beads. In this case, cell walls became much smaller fragments than the dimension of whole cells. This made much easier the differential centrifugation to separate cell walls from whole cells. This cell wall preparation was only slightly active in producing immunity in mice, when administered intraperitoneally without oil. However, as stated before (Kanai, Youmans and Youmans, 1960), they were active with the aid of oil in producing delayed sensitivity in guinea pigs.

\section{f) Immunogenicity of particulate fraction.}

Youmans, Millman and Youmans (1955) and Youmans, Youmans and Millman (1957) have reported that enzymatically active particles collected by ultracentrifugation from extracts of mechanically broken mycobacterial cells (viable H37Ra) are immunogenic for mice. Because of the presence of most of the Krebs' cycle enzymes, this particulate fraction was initially considered as mitochondria-equivalent structures of the tubercle bacillus (Millman and Youmans, 1955). In their experiments, the immunizing agent was injected intraperitoneally into mice being followed by intravenous challenge with 0.5 to $1 \mathrm{mg}$ of $\mathrm{H} 37 \mathrm{Rv}$ tubercle bacilli 4 weeks later. Evaluation of protection was made by comparison of percentage of 30 day survivals between vaccinated and unvaccinated groups. The rationale for this method was presented by Youmans and Youmans (1957). As stated before, one of the advantages of this method is that it can measure pure vaccination effect excluding the immunity due to challenge per se.

The immunizing ability of the particulate fraction was then confirmed by Kanai and Youmans (1960) in comparison with that of cell walls. At least in the same experimental conditions as above and without adjuvant, the particulate fraction showed a superior immunogenicity. In addition, it was found by Kanai, Youmans and Youmans (1960) that the particulate fraction does not sensitize guinea pigs to tuberculin in a delayed type, but cell walls do. Nevertheless, the immunogenicity of the particulate fraction appeared extremely labile in various environmental conditions. For example, the immunogenicity was sensitive to the hydrogen-ion concentration; the optimal activity was found at $\mathrm{pH} 6.8$ to 7.0. The fraction prepared in sucrose buffer at $\mathrm{pH} 7.3$ to 7.6 was much less active than that prepared in sucrose buffer at $\mathrm{pH}$ 7.0. The detergent sodium lauryl sulfate inactivated the immunogenicity. Temperature higher than $4 \mathrm{C}$ also inactivated the immunogenicity (Youmans and Youmans, 1964a). Therefore, in order to forward the investigation along this line, it was thought essential to devise some 
methods to stabilize the fraction. Then, efforts of Youmans and Youmans $(1964 \mathrm{~b})$ have obtained an observation that the use of $0.44 \mathrm{M}$ sucrose and the presence of $3 \times 10^{-2} \mathrm{M} \mathrm{MgCl}_{2}$ during the preparatory processes markedly increased the immunogenicity of the particulate fraction. It must also be noted that the addition of $\mathrm{MgCl}_{2}$ to the particulate fraction after it had been prepared did not increase the immunogenicity.

At this stage of investigation, however, the nature of the labile immunogenic particulate fraction was still obscure. Then, Youmans and Youmans (1964c, $1965 \mathrm{~b}$ ) had some indirect evidence to prove that the fraction consists of two immunologically different subfractions; probably ribosomes and fragments of the cytoplasmic membranes. Interesting enough, their carefully controlled experiments indicated a possibility that the immunizing component of the particulate fraction is a substance (ribosomal) which can be sedimented at $144,000 \times \mathrm{g}$, but for maximum immunization a labile, probably membraneous moiety of the mycobacterial cell, which has the properties of an adjuvant, is required. At the same time, it was found that Freund's adjuvant can be replaced with such a membraneous fraction. In other words, ribosomal subfraction can be as good an immunogen as the original particulate fraction, if it is incorporated into Freund's adjuvant. This type of experiment was possible using various membrane-disrupting agents.

Finally, they (Youmans and Youmans, 1966a) isolated a ribosomal fraction from H37Ra viable cells by the use of sodium didocyl sulfate as the membrane-disrupting agent. The sample contained $50 \%$ RNA and 15 to $20 \%$ protein, and was highly immunogenic in CF-1 mice when used with the aid of Freund's adjuvant. For the preparation of ribosomal fraction, the presence of $10^{-4} \mathrm{M} \mathrm{MgCl}_{2}$ was satisfactory.

The immunogenicity of this ribosomal fraction was soon found to be sensitive to ribonuclease $(50 \%$ decrease) but resistant to trypsin. Crude ribonucleic acid extracted with alcohol from the fraction was alsoimmunogenic in the dose of $50 \mu \mathrm{g}$ (80\%30 day survivals). In contrast, yeast RNA was not immunogenic (Youmans and Youmans, $1966 \mathrm{~b})$. The above is a brief outline of the ten-year investigation made by Youmans and his associates on the labile immunogenic substance of tubercle bacilli.

Now, we are placed in a position to raise questions whether only ribosomal ribonucleic acid is protective or other kinds (messenger, transfer or else) are also protective, and in what way ribosomal ribonucleic acid can stimulate the host to produce protection. Youmans and Youmans (1966 b) have presented several hypotheses as to the mechanism of protective ribosomal RNA; stimulation of macrophage proliferation, stimulation of production of inducible enzymes which might be growth-inhibitory for tubercle bacilli, and function as a template for production of protective antigens after it has been ingested into macrophages.

As stated elsewhere, viable vaccines are generally immunogenic because of their multiplication to some extent in the host. This appears contradictory to the concept of immunogenic RNA being a factor responsible for the immunogenicity of viable vaccine. However, Doi and Igarashi (1964) reported that the ratio between soluble RNA and ribosomal RNA decreases in bacteria during growth and increases while dormancy. This information is most interesting in view of the investigation on protective RNA as discussed above.

Eda (1964) isolated a ribosmal fraction from BCG organisms and was successful in demonstrating that the fraction was active in incorporating ${ }^{14} \mathrm{C}$-amino acids into its protein moiety in the presence of ATP and its generator. However, it is too premature to consider tuberculous infection and immunity from such a standpoint of molecular biology. 
Matsuura, Oka and Yshioka (1960) also studied on the immunogenicity of intracellular particulats fractions of virulent and avirulent tubercle bacilli ( $\mathrm{H} 37 \mathrm{Rv}$ and $\mathrm{H} 37 \mathrm{Ra})$. In order to secure the sterility of this fraction, they irradiated the material with ultraviolet light for 3 to 4 minutes before use. Evaluation of protection was made in almost the same way as Youmans' method. They could demonstrate a high immunogenicity of the fraction.

On the other hand, Ribi et al. (1965) compared the immunogenicity of the particulate fraction prepared by Youmans' method with the oil-disrupted product. Evaluation of protection was made by two different methods; percentage of 30 day survival of mice of intraperitoneal vaccination and massive intravenous challenge, and lung lesion observation in mice of intravenous immunization and aerosol challenge. Their results favored the immunogenicity of oil-disrupted products.

As discussed above, the immunogenicity of the cell walls and the intracellular particulate fraction has been supported with some reservation by limited investigators. On the other hand, as for the soluble (cytoplasmic) fraction none has ever supported its protectivity.

\section{g) Immunogenicity of defatted whole cells.}

Until recently, more attentions have been paid to chemically extracted lipids of the tubercle bacillus asking for a possible protective agent than to the residue (defatted bacilli), as reviewed by Crowle (1958). However, the higher immunigenicity of defatted tubercle bacilli has been demonstrated by some authors in the past several years. Tsumita et al. (1960) extracted with $90 \%$ phenol and buffer a sample of dried bovine tubercle bacilli (BCG) previously defatted with chloroform, and obtained four fractions of different chemical and biological properties. Among them, a phenol insoluble and buffer insoluble bacterial residue was mostly composed of protein with a small amount of fatty acids ( $3 \%$ ) of a long chain, and the residue conferred to guinea pigs a delayed sensitivity to tuberculin and protection against challenge with virulent tubercle bacilli. Terai and Nagasuga (1963) also examined various lipid fractions and the residue for their immunogenicity, and reached an observation that wax $B$, phosphatide and the residue were protective.

However, a more thorough study on the immunogenicity of defatted tubercle bacilli has been made by Smith and his associates (Smith and Robertson, 1962) (Erikson and Smith, 1962) (Fregnan and Smith, 1963) (Smith et al., 1964) (Kanai, Wiegeshaus and Smith, 1966). First, they observed that bacillary residue resulting from extraction with neutral organic solvents of a human strain of tubercle bacilli (DFB) was protective in guinea pigs with the aid of adjuvant, while cord factor, wax D, PMKo and typhoid polysaccharide were not in the same experiment. The immunogenicity of DFB was almost equal to BCG in the dose of $50 \mu \mathrm{g}$. DFB was acid-fast. However, the alkalineethanol treatment and disrution in oil made them nonacid-fast without destroying the immunogenicity. Evaluation of protection was made by both subcutaneous and airoborne challenge followed by visual and microscopic examination of lesions and enumeration of viable counts in the tissues. However, a comparison of immunogenicity on a weight basis between DFB and the original strain from which DFB was prepared has not yet been conducted. Besides, it is not certain as yet whether such a high immunogenicity of DFB in oil is peculiar to the strain used or is common to all strains of virulent human tubercle bacilli. 
h) Immunogenicity of the substances extracted chemically from tubercle bacilli.

Stöss and Herrman (1965) isolated seven lipid components from tubercle bacilli. Serological activity of fractions was examined and only phosphatide, wax B and wax D were found active. The activity of wax D has a strain specificity. However, unlike the observation of Terai and Nagasuga (1963), none of the 7 fractions was protective. On the other hand, an evidence that the active principle of protective antigen is resistant to trypsin was presented by Crowle (1963), and Crowle and Teranuma (1964), suggesting another direction of search for immunizing antigens. Crowle's work is now open to confirmation by other investigators.

More recently, Yoneda and his associates (1966) isolated a protective antigen (designated as CULF) which is an extracellular product of BCG growing exponentially in a shaking culture. The medium was a semi-synthetic liquid medium containing Mueller and Miller's II solution, Tween 80, asparagine, glycerine, casamino acids, and phosphates. The active principle was precipitated from the cell-free culture filtrate by $80 \%$ saturation with ammonium sulfate. The immunogenicity of CULF was compared with that of living BCG vaccine and assayed on two different criteria: (1) survival time of CF-1 mice following challenge with $M$. bovis (Ravenel), (2) viable counts of infectious bacilli in the lungs of CF-1 mice challenged with a relatively smaller dose of Ravenel strain. CULF-vaccination was done by the subcutaneous route with the aid of Freund's incomplete adjuvant. BCG-vaccination was done intraperitoneally without the adjuvant. Vaccination-challenge interval was 2 weeks. In both evaluation methods, it was found that CULF is as effective as BCG in protection of CF-1 mice from such challenge infections. The optimal dosis of CULF for the maximum effect was $5 \mathrm{mg}$ per mouse, and the higher doses were less effective, suggesting possible immunological paralysis. Without the adjuvant, CULF showed no protective effect. On the other hand, their $\alpha$ and $\beta$ antigens (Fukui et al., 1965) (Yoneda, Fukui and Yamanouchi 1965), extracellular proteins of mycabacteria, were not protective and did not exert immunological paralysis in this respect.

\section{Nonspecific and Broadly-Specific Resistance to Tuberculous Infection}

a) Immunity to tuberculous infection produced by vaccination with unclassified mycobacteria.

Cross-protection between virulent tubercle bacilli and unclassified mycobacteria has been a matter of theoretical interest and also a problem of practical importance. Freerksen (1959) was the first who was engaged in experimental research work to answer this question. He immunized guinea pigs with viable cells of various mycobacteria and then infected them with $M$. tuberculosis. Among the mycobacteria used as vaccines were M. avium, BCG, H37Ra, Group III (Batty type) atypical mycobacteria, Group II scotochromogenic mycobacteria, and M. kansasii. BCG and H37Ra were found to be the highest in the protective effectiveness, and $M$. kansasii was slightly less immnnogenic than these two. Group III and $M$. avium were a little less immunogenic than $M$. kansasii, and the scotochromogenic strains were only slightly active.

Youmans, Parlett and Youmans (1961) reported similar studies in mice with closely parallel results to those of Freerksen (1959). The evaluation of protection was done by comparative observation of percentage of 30 day survivals of mice vaccinated with $1 \mathrm{mg}$ of viable cells of each strain and challenged intravenously with $1 \mathrm{mg}$ of $\mathrm{H} 37 \mathrm{Rv}$ strain 28 days later. The immunogenicity of $M$. kansasii was equivalent to BCG vaccine, but 
that of the rapid grower was negligible.

Palmer and Hopwood (1962) confirmed the results of Freerksen (1959) and Youmans et al. (1961) in their guinea pig experiment. Klugh and Pratt (1962) immunized guinea pigs with $\mathrm{BCG}$ vaccine and a photochromogenic strain. The protection was slightly higher with BCG than with the photochromogen. Satake (1963) could also demonstrate the high immunogenicity of $M$. kansasii in guinea pigs. From the observation that the animals vaccinated with $M$. kansasii were not sensitized to OT but protected from challenge infection with virulent tubercle bacilli, he concluded that allergy and immunity are not always parallel in tuberculosis.

Larson and Wicht (1963) have conducted aerosol vaccination experiments using unclassified mycobacteria. The results were that $M$. kansasii was equivalent to H37Ra in conferring protection to mice against tuberculous infection. $M$. balnei was a little immunogenic, but Group II, III and IV unclassified mycobacter!a were not. At the same time, it was found that $M$. kansasii administered aerogenically could produce extensive granulomatous lesions in the lungs. Toyohara and Shimoide (1964) observed that superinfection with $M$. kansasii enhanced tuberculous infection, deteriorating the primary lesions and accelerating the multiplication of infecting tubercle bacilli due to the primary infection. An additional confirmation concerning the high immunogenicity of M. kansasii was obtained by Siebenmann and Barbara (1964) in the mouse protection test. In their result, $M$. kansasii was equivalent to BCG in the immunogenicity. Reversing the experimental process, BCG vaccination was found to be effective against challenge infection with $M$. kansasii. On the other hand, Koyama (1964) (1965) obtained somewhat different results concerning the immunogenicity of unclassified mycobacteria. In his mouse protection experiments, $M$. boris was used as a challenge strain. A scotochromogenic strain (p-6) was found protective to the same grade as BCG vaccine, and $M$. kansasii ( $\mathrm{p}-8)$ and a nonphotochromogenic strain (p-7) were less immunogenic. In fact, Siebenmann and Barbara (1964) observed that $M$. kansasii was less effective in immunizing mice against challenge infection with $M$. boris than aginst that with $M$. tuberculosis. Inui (1963) observed that mice pretreated with unclassified mycobacteria increased the susceptibility to bacterial endotoxin just like BCG-immunized mice.

Cross immunity between tubercle bacilli and unclassified mycobacteria may be of such a nature as a combination of specific, broad-specific and nonspecific resistances. A further discussion of the problem including epidemiological aspects is to be referred to the recent review of Youmans (1963).

b) Increase of resistance to tuberculous infection induced by vaccination with bacteria other than mycobacteria.

For many years, there have been discrete observations that vaccination with killed gram-negative bacteria can enhance resistance to tuberculous infection (Nukada and Ryu, 1936) (Nukada and Utsunomiya, 1956) (Waaler, 1956) (Dubos and Schaedler, 1956) (Nyka, 1956). Interesting enough, these protective bacteria were intracellular parasites such as typhoid bacilli, gonococci, pertussis vaccine and brucella. In this regard, the cross-protection as above might be called "immunity of broad specificity" as suggested by Williams and Dubos (1959). Besides, as pointed out by Crowle (1958), antitubercular resistance induced by heterologous bacteria appears to depend upon the common route shared by vaccination and challenge, and the site of nonspecific defense mechanisms apears to reside in phagocitic cells (Elberg, Schneider and Foung, 1957).

According to Rowley (1955, 1956), Shilo (1959), and Motomiya and Kayabe (1960), 
a factor of heterologous bacteria responsible for induction of nonspecific resistance is cell walls. Most recently, Ribi, Brehmer and Milner (1966) showed that intraperitoneal vaccination with oil-treated cell walls of $S$. typhimurium, Br. abortus, and L. monocytogenes could protect mice from a fatal intravenous challenge with virulent tubercle bacilli. However, it must be noted here that vaccination and challenge interval was 24 hours. Thus, they stated that mice were protected aginst a heavy intravenous challenge with M. tuberculosis principally with nonspecific factors; after a 30 day interval, protection appeared to depend upon a mixture of specific and nonspecific effects. Therefore, the nonspecific resistance to tuberculous infection induced by heterologous microorganisms appears to be a matter of experimental interest but not of practical importance.

c) Increase of resistance to infections other than tuberculosis induced by mycobacterial components.

Dubos and Schaedler (1957) observed the increase of resistance to infections with Staph. aureus and K. pneumoniae in mice vaccinated with phenol-killed BCG. The same result was also obtained by Williams and Dubos (1959) who used a methanolextract of BCG as an immunizing agent against Staph aureus infection in mice. In these experiments, the vaccination-challenge interval was 2 weeks. Based upon these previous informations, Tsuchiya and Yamazaki (1964) attempted to isolate a factor responsible for this nonspecific increase of resistance to infection from phenol-killed BCG cells. The cells were defatted first by the method of Lederer and Asselineau and then with $1 \% \mathrm{HCl}$ ether-ethanol. The defatted cells were extracted three times with $\mathrm{N} / 10$ acetate buffer ( $\mathrm{pH}$ 4.0). The extract was dialysed against running water, concentrated under vacuum, and lyophilized. The capacity of each fraction to increase nonspecific resistance was examined by intravenous challenge with Staph. aureus 308 A-1 against the mice vaccinated intraperitoneally with the fraction suspended in Drakeol No. 35. The effectiveness was found only in the final residue. This activity was not destroyed by Pronase-P treatment, oxidation with $\mathrm{NaIO}_{3}$ or reduction with $\mathrm{NaBrH}_{4}$, suggesting that the factor might not be protein nor polysaccharide. On the other hand, their separate experiments indicated that BCG cell walls are active in this respect but their lipopolysaccharide is not. Hence, those authors concluded that the factor responsible for induction of nonspecific resistance is a substance present in the cell wall, of nonprotein, nonpolysaccharide, and nonlipopolysaccharide nature. Youmans and Youmans (1965 c) also observed that heat-killed H37Ra cells had a "nonspecific" immunizing component, which may be a lipopolysaccharide differing from the classical "endotoxins". They claimed that at least three independent mechanisms are operative in tuberculous immunity; (i) a nonspecific stimulation of the reticuloendothelial system similar to that produced by endotoxin in gram-negative bacteria, (ii) a probably more specific immune mechanism which may or may not be mediated by an antibody, and (iii) the rapid accumulation and proliferation of macrophages. This idea is called by them as the "multiple response" theory. More recently, Fox et al. (1966) isolated cell walls from M. phlei and proved their nonspecific immunogenicity in mice and guinea pigs challenged with Salmonella enteritidis and Staphylococcus aureus. They attributed this particular protection to lymphoid hyperplasia in the spleen and Kupffer cell proliferation of the liver induced by the cell wall vaccine.

Ribi, Brehmer and Milner (1966) studied the specificity of cell wall immunogenicity in mice and suggested that the nonspecific protective effect of mycobacteria probably is not dependent upon endotoxin nor upon endotoxin-like substances. The nonspecific 
stimulation of immunologic machinery by mycobacteria might explain the mechanism of complete Freund's adjuvant at least partially, and it is suggested that the whole mycobacterial cells in the adjuvant can be replaced with their cell walls.

Though all the literature cited above are concerned with mycobacterial cell walls, Hedgecock (1964) reported that culture filtrates of $M$. tuberculosis conferred on mice protection against infections with Diplococcus pneumoniae and Klebsiella pneumoniae. However, it will be premature to discuss this problem at this moment.

d) Increase of resistance to tuberculous infection induced by nonionic surface active agents.

Since the first observation of Cornforth et al. (1951) that a commercially available nonionic detergent, Triton WR-1339, and other synthetic macromolecular products, suppressed the development of experimental tuberculosis in mice, this phenomenon has been attracting attention of many workers. Most recently, Hart and Rees (1960) and Niffenegger and Youmans (1960) studied the antitubercular effect of macrocyclon, one of such detergents, in mice. In the mice injected with macrocyclon 28 days prior to challenge, the growth of challenge tubercle bacilli was greatly inhibited and the mouse survival time was prolonged. In this respect, macrocyclon was almost comparable with $\mathrm{BCG}$ vaccine. The mechanisms by which the detergents can induce protection were discussed at length by Lovelock and Rees (1955). One possibility was that the detergents do penetrate macrophages and render ingested tubercle bacilli vulnerable to the destructive defense mechanisms of the phagocyte by stripping or modifying a protective lipid outer layer. They presented an indirect evidence for this assumption. However, the outer membrane of macrophages might also be affected by the detergents because of the possible high content of phospholipids.

At any event, it might be that the host-parasite relationship between tubercle bacilli and macrophages is modified in the cellular or subcellular level by the presence of the detergents. In this connection, the information that Triton WR-1339 injection exerts influence on the properties of rat liver lysosomes is most stimulative for the future study in this field. There will be a gocd possibility that scme light is shed on the nature of acquired resistance to tuberculous infection from the particular type of model experiment using antitubercular protective detergents.

\section{Mechanism of Acquired Resistance to Tuberculous Infection}

a) Role of antibody.

It has been acknowledged that sera obtained from actively immunized individuals do not kill tubercle bacilli even in the presence of complement (Middlebrook, 1965). Besides, attempts at passive transfer of acquired resistance to tuberculosis using immune serum have been unsuccessful so far (Raffel, 1956). Therefore, it is a generally accepted view that antibodies are not playing any significant role in acquired resistance to tuberculosis. The reason why tubercle bacilli are not sensitive to antibodies is still obscure. However, it will be speculated that the bacilli surviving within macrophages can escape from exposure to circulating antibodies and also that the surface structure characteristic to tubercle bacilli is of such a nature that they can resist antibodies. According to recent studies of Muschel and Jackson (1966) and Bladen, Evanc and Mergenhargen (1966), the locus of the antigen-antibody complex which activate complement is probably on the cell wall, but the complement target may be the cell membrane. If this situation could be true in the case of tubercle bacilli, their lipidic surface and their slow growth would 
be unfavorable conditions for the bactericidal action of antiserum. However, as we have already discussed, the acquired resistance to tuberculosis is of a bacteriostatic, rather than bactericidal nature. Therefore, we are more interested in the presence of antibodies which might bring infecting tubercle bacilli into bacteriostasis. Such an example can be found in the infection with Trypanosoma lewisi. "Ablastin" is an antibody which has been found to have the property of inhibiting the multiplication of Trypanosoma lewisi. Moulder (1948) showed that ablastin can act on multiplying trypanosoma to bring their active oxidative assimilation into the metabolism of maintenance. More recently, Taliaferro and Pizzi (1960) demonstrated that ablastin can inhibit nucleic acid and protein synthesis of infecting Trypanosoma lewisi. This kind of antibody which is specifically active against tubercle bacilli has not yet been discovered. However, if it were found, it would help us greatly to understand the nature of the acquired resistance to tuberculosis.

On the other hand, there has been a concept of cytophilic antibodies in association with tuberculin hypersensitivity. Quite recently, Boyden and Sorkin (1960) and Boyden (1964) have proved experimentally the presence of such antibodies. Boyden (1964) showed in the guinea pig anti-sheep red cell serum the presence of an antibody which could selectively bind to homologous peritoneal macrophages and confer upon them the ability to absorb sheep red cells. Uhr (1965) studied on the mechanism of binding of cytophilic antibodies on macrophages and explained the sequence of the phenomenon as follows: (1) a binding site (or sites) on the heavy chains of antibody gamma globulin is exposed as a result of the change in antibody configuration following its combination with antigen; (2) the gamma-globulin binding site then interacts with a receptor on the macrophage surface; (3) the complex is phagocytized. Berken and Benacerraf (1966) also studied on the properties of antibodies cytophilic for macrophages. The antibodies possessing cytophilic activity for macrophages were found to be mostly, if not all, the complement binding 7s $\gamma_{2}$-population of guinea pig antibodies. Cytophilic antibodies were also demonstrated in rabbit and mouse antisera to sheep red cells. Confirming Uhr's results, the binding site for macrophages was found to reside on the Fc fragment of the $\mathrm{H}$ chains, and to be destroyed by pepsin hydrolysis or reduction and alkylation. The binding reaction was reversible at $37 \mathrm{C}$. They suggested that the primary biological usefulness of cytophilic antibodies resides in their capacity to opsonize soluble and particulate antigens to allow their uptake by macrophages. The possibility that these newest observations will be closely associated with the nature of tuberculous infection and immunity in some way will be supported by the following informations.

Mackaness (1964) has reported that macrophages from immunized mice proliferate in vivo when in contact with the sensitizing bacterial antigens and evolve into cells more able to suppress nonspecifically the growth of ingested bacteria. Peritoneal macrophages from sensitized guinea pigs clump and adhere to peritoneal surfaces in vivo when antigen is injected (Nelson and Boyden, 1963). These same cells in vitro fail to migrate under the effect of antigen (David, Lawrence and Thomas, 1964a, b) (Carpenter and Brandriss, 1964) (David, 1966). These responses of peritoneal macrophages were observed only in animals immunized with antigen and mycobacteria and have been considered to be cellular manifestation of delayed hypersensitivity reactions. In addition, Daniel (1965) showed that rabbits responded with production of $\gamma_{1}$ antibodies to injection with OT and PPD, but with $7 \mathrm{~s} \gamma_{2}$ antibodies to injection with OT incorporated into adjuvant. He stated that a stronger stimulation will be needed for production of $7 \mathrm{~s} \gamma_{2}$ antibodies, which are considered as cytophilic antibodies as discussed above. 
In view of these facts, cytophilic antibodies must be a subject of future study in connection with the resistance to tuberculous infection, even though they have no direct antimycobacterial properties. In the following section, the role of phagocytic cells in antitubercular protection will be discussed as the most widely accepted view of tuberculous immunity. However, it must be kept in mind as one possibility that such cellular immunity could be mediated by humoral factors such as described above.

\section{b) Role of phagocytic cells (cellular immunity).}

It can be stated that the concept of cellular immunity in tuberculosis was given a definite shape by a classical experiment of Lurie (1942). He showed that when the washed monocytes of an immunized rabbit are transferred into the anterior chamber of the eyes of a normal rabbit, they show in this place the ability to suppress the multiplication of tubercle bacilli, and in contrast, the serum of immunized animals does not affect the rate of bacterial multiplication when it is added along with normal cells under the same condition. This pioneering experiment was repeated and extended by Suter (1953), Mackaness (1954), Berthrong and Hamilton (1959) and many others reaching the same or different conclusions. Suter (1953) observed in his tissue culture experiments that monocytes obtained from the peritoneal cavity of guinea pigs immunized with BCG had an increased ability to inhibit the multiblication of tubercle bacilli than did the same type of cells from normal guinea pigs. On the other hand, Mackaness (1954) could not find any difference in this respect between the monocytes of immunized rabbits and those of normal rabbits. In spite of this observation, his idea of cellular immunity was established some years later on the basis of another line of research. Fong, Chin and Vickrey (1963) and Sugihara, Brobs and Smith (1965) have observed that monocytes from immunized guinea pigs and rabbits were protected from the primary cytotoxic and necrotizing effect of virulent tubercle bacilli. In addition, some evidences were presented by Fong, Schneider and Elberg (1957) and Hsu (1965 a) to prove that specific immune serum has a factor or factors which make the monocytes acquire such a property. Hsu (1965 b) has observed also that macrophages of the rabbits of native resistance to tuberculous infection are more resistant to the cytotoxic effect of the bacilli than those of the genetically sensitive animals.

We have already discussed before regarding some possible mechanisms accounting for the inhibition of intracellular multiplication of tubercle bacilli as a general microbiological problem in association with phagocytosis. Quite recently, another line of research has been conducted by Mackaness (1964), Miki and Mackaness (1964), and Khoo and Mackaness (1964) to explain the nature of cellular immunity on the basis of delayed hypersensitivity. According to these authors, the hypersensitive state of the macrophages itself does not mean the bactericidal nor bacteriostatic ability against ingested tubercle bacilli, but the hypersensitive response, probably on the surface of macrophages, alter the metabolism of macrophages so that an environment might be established intracellularly which is in some way inimical to the bacilli. Of utmost interest is their observation that the hypersensitive response is of course immunologically specific, but the resulting growth-inhibitory conditions are not. For example, the intracellular environment produced by the hypersensitive response is growth-inhibitory not only to tubercle bacilli, but also to other intracellular microorganisms such as Listeria monocytogenes or Brucella abortus. Reversing the process, if the macrophages hypersensitive to Listeria Brucella come into contact with those microbes, their response creates an environment where the growth of tubercle bacilli is inhibited. In this sense, immunity in tuberculosis 
would be constituted from the two sequential events, the first being specific and the second nonspecific. In addition, Khoo and Mackaness (1964) have suggested that the contact between allergic macrophages and corresponding antigen may lead to proliferation or destruction of the cells depending on the intensity of the hypersensitive reaction. In the case of cell multiplication, intracellular environment might be unfaborable to the growth of the bacilli, and the reverse might be the case in the destructed macrophages.

In fact, there are some evidences indicating that the elevated metabolic activity of monocytes is responsible for resistance to tuberculous infection in some way (Allison, Zappasodi and Lurie, 1962). Of particular interest is the observation of Beaconsfield, Ginsburg and Kasinski (1965) that glucose metabolism via pentose phosphate cycle is elevated during cell replication as an immunologic response.

Turning to another topic of cellular immunity, the problem of passive transfer of tuberculous immunity by immunized cells will be discussed here. Sever (1960) may be the first who performed this work. He demonstrated prolongation of the survival time of mice infected with a massive dose of virulent tubercle bacilli after passive transfer of monocytes from immunized mice. This work was soon confirmed by Millman (1962) in a slightly modified condition. He was successful in his attempts only when the peritoneal exudate cells were transferred after in vitro preincubation with tubercle bacilli. Neither immune cell lysates nor bone marrow could be substituted for the peritoneal exudate cells. The effect of preincubation with the bacilli on the cells might be interesting in view of the theory presented by Mackaness and his associates as discussed before. Further confirmations were made by Asaba et al. (1964a, b) using isologous and homologous mice. In their experiments, however, protection in the recipient animals was evaluated by inhibition of the multiplication of the challenge strain in the lungs and spleen. Unlike the case of Millman, they could transfer the protective ability also using sonic lysate of the immune cells. Going further beyond the lysate experiment, Fong, Chin and Elberg (1963) demonstrated that rabbit macrophages were endowed with cellular resistance against tubercle bacilli when the animals were injected with ribosomes or ribosomal RNA of BCG-vaccinated rabbits. Similar observations were also obtained by Sato and Mitsuhashi (1966) in the relation between ribosomal fraction of mouse immune macrophages and Salmonella entiritidis which is also an intracellular parasite. These studies are apparently indicating the opening of molecular approach to tuberculous immunity.

However, future study will be required to reach a decisive conclusion concerning to what extent this protective function induced by passive transfer of macrophages or of their ribosomal fraction is specific. Besides, it is still difficult at this moment to interpret the above information in a close association with other cellular and humoral factors in tuberculous immunity.

c) Role of delayed hypersensitivity.

In spite of the well-documented observation that immunity in tuberculosis is always accompanied by delayed sensitivity, the question has often been raised as to whether delayed sensitivity is a requisite for immunity. This problem can be investigated by attempting to produce a situation in which animals are immune and not hypersensitive.

The first approach of this kind was of course desensitization experiments which were conducted by many workers with controversial results during the period from 1930 to 1940. These works are thoroughly discussed in the monographs of Pinner (1945) and Rich (1951). Because of the danger of focal reaction, desensitization is often hazardous. 
Only when tuberculous animals are treated with repeated, gradually increasing doses of tuberculoprotein without causing severe focal reactions desensitization can be accomplished accompanying improvement of tuberculous infection, thus indicating apparent dissociation between protection and hypersensitivity. In contrast, desensitization with extreme focal reactions enhances tuberculous infection and eventually leads to the death of animals. Therefore, the outcome of desensitization experiment appears largely to depend upon the conditions resulting from the contact between tuberculoprotein and hypersensitive tissue cells. In this connection, the discussion made by Khoo and Mackaness (1664) is most suggestive. They explained that macrophage proliferation caused by a moderate antigenic stimulation can suppress the multiplication of ingested bacilli, but macrophage destruction caused by an extreme antigenic stimulation may enhance the multiplication of ingested bacilli. Therefore, it would be a more reasonable thought that such an increased resistance caused by desensitization procedure is established not because of a desensitized state of the host, but because of the intermediate immunological processes leading to desensitization. After all, it would be concluded that desensitization experiments do not provide us a clue to grasp the relation between immunity and allergy. Yanagisawa, Katsuyama and Kanai (1956) have suggested this possibility on the basis of their desensitization experiments.

Another approach was suggested by the papers reporting that tuberculin sensitivity can be suppressed to varying degrees in guinea pigs and rabbits by immunosuppressive antimetabolites (Friedman, Buckler and Baron, 1961) (Hoyer, Hoyer, Good and Condie, 1962) (Friedman and Buckler, 1963) (Friedman, 1964) (Maeda, Arima and Yamamoto, 1964). Through the use of an immunosuppressive drug to inhibit delayed sensitivity during vaccination and infection, animals would be rendered immune and not sensitive only if the mechanism producing delayed sensitivity differed from that producing immunity and if, at the same time, the former mechanism was more susceptible to the drug.

Nemoto et al. (1964) treated BCG-vaccinated guinea pigs with 6-mercaptopurine to suppress the development of tuberculin hypersensitivity and then challenged them with virulent tubercle bacill. The result was that the development of tuberculin hypersensitivity was inhibited with a simultaneous loss of resistance to challenge infection. Almost the same result had been obtained by Prickard and Hayes (1961) in guinea pigs and also in man, as a chance observation, who was treated by methotrexate for leukemia to result in exacerbation of his latent tuberculosis. However, it must be noted that enhancement of infection reported by the above authors was accompanied by severe drug toxicity. Just like the case of tuberculin desensitization experiment accompanied by extreme focal reactions, it would be difficult to evaluate the immunological significance of these experiments using immunosuppressive agents. Kanai, Wiegeshaus and Smith (1966) have also attempted an experiment to suppress hypersensitivity in guinea pigs vaccinated with a nonliving vaccine in adjuvant by the use of methotrexate. The animals were challenged with virulent tvbercle bacilli by the respiratory route. Continuous treatment of vaccinated animals with the drug showed only a temporary inhibition of delayed sensitivity, but the protective effects of the vaccine were decreased and the infection in unvaccinated animals was extremely enhanced. The differences in the rate of body weight increase between treated and untreated groups in the experiment was not sufficient to reflect serious methotrexate toxicity.

These results are not compatible with the informations that macrophages are required in the initial steps of the immune response involving particulate antigens (Fishman and 
Adler, 1963) and that these steps are not blocked by methotrexate (Turk and Stone, 1963). However, evolution of macrophages and lymphocytes and the interrelation between them are still an unsettled problem in hematology. Therefore, it would bo too premature to draw a conclusion only from the observations discussed above.

The final approach to analyse the relation between immunity and hypersensitivity might be to detect antigens which sensitize animals without conferring protection or confer protection without producing sensitivity. Actually, mycobacterial components possessing such immunological properties have been reported by not a few authors as reviewed by Crowle (1958). Nevertheless, these observations have not always been supported by others as a convincing evidence of separation between immunity and hypersensitivity.

Whereas the delayed hypersensitivity is an entity, there is a good possibility that protection is a net result of multiple events in the sensitized individual. Besides, the delayed hypersensitivity is a concept of a kind of potentiality, and what we can observe actually is a hypersensitive reaction. Therefore, our present problem will be whether a hypersensitive reaction which occurs at the time of entrance of tubercle bacilli will bring benefits to the host or not. Thus, the relation between immunity and allergy becomes sometimes a matter of phylosophy, terminology or definition, diverting from the recognition of facts themselves.

\section{d) Other mechanisms.}

In various parts of this review, the author has been pointing out several factors which might account for increased resistance to tuberculous infection; for example, lysosomal components (such as cationic proteins, hydrolysing enzymes and lysozyme), phagocytin, lactic acid, and gaseous environment. Even if these agents should play an important role in resistance to tuberculosis, there would be a good possibility that the agents are mobilized against tubercle bacilli being mediated by immunologic stimulation. Recently, additional observations concerning tissue components possessing antimycobacterial activity were obtained by Youmans and Youmans $(1962 \mathrm{a}, \mathrm{b})$ and Ramseier and Suter (1964a, b).

The former authors isolated a substance, called mycosuppressin, in the lungs of guinea pigs and rabbits vaccinated with BCG or with a particulate immunizing fraction isolated from H37Ra cells. It was not found in the lungs of unvaccinated animals. Mycosuppressin inhibited the endogenous respiration of $\mathrm{H} 37 \mathrm{Rv}, \mathrm{H} 37 \mathrm{Ra}$, and $M$. smegmatis, but increased that of M. phlei, Staphylococcus aureus, and Escherichia coli. Mycosuppressin is stable at $\mathrm{pH} 6$ to 7 and at $98 \mathrm{C}$, nondializable, soluble in alconol and acetone, insoluble in ether and water, and inactivated by serum and bovine serum albumin. It can be absorbed to mycobacterial cells under appropriate conditions. When mycosuppressin was administered to normal mice prior to infection with virulent tubercle bacilli, no indication of a favorable effect on the course of the infection could be obtained. However, when a suspension of virulent tubercle bacilli was exposed to mycosuppressin of virulent tubercle bacilli for from 1.25 to $3.25 \mathrm{hr}$ prior to infection, the survival time of the mice was greatly prolonged in comparison with mice receiving untreated tubercle bacilli. These observations are particularly interesting in view of the more recent papers of Zeya and Spitznagel (1966a, b) reporting that cationic proteins of polymorphonuclear leukocyte lysosomes can inhibit oxygen uptake of bacterial cells and damage the permeability barriers of the cells.

On the other hand, Ramseier and Suter $(1964 \mathrm{a}, \mathrm{b})$ observed the inhibition in vitro 
of tubercle bacilli by disrupted mononuclear cells obtained from normal and BCG-immunized guinea pigs, and the factor responsible for this inhibition was found to be a heat-labile nuclear fraction. This information reminds us of the former observation of Dubos and Hirsch (1954) that a peptide preparation derived from calf thymus had an antimycobacterial activity.

There is, however, little convincing evidence at this moment which would indicate that these tissue components are the ultimate factor responsible for acquired resistance to tuberculous infection.

\section{REFERENCES}

Allison, M. J., Zappasodi, P. And LuRie, M. B. (1962) : Metabolic studies on mononuclear cells from rabbits of varying genetic resistance to tuberculosis. Am. Rev. Resp. Diseases, 85, 364-370.

Allison, M. J., Gerszten, E., Brummer, D. L. And Carter, S. (1965) : Enzymatic activity of leucocytes from normal and from tuberculous subjects. Am. Rev. Resp. Diseases, 91, $713-718$.

Andeeron, R. J., Reeves, R. E., Creighton, M. M. And Lathrop, W. C. (1943) : The chemistry of the lipids of tubercle bacilli. LXV. An investigation of tuberculous lung tissue. Am. Rev. Tuberc., 48, 65-75.

ARMStrong, B. A. AND SwARD, C. P. (1966) : Electron microscopy of Listeria monocytogenesinfected mouse spleen. J. Bacteriol., 91, 1346-1355.

ARTMAN, M. AND BeKIERKUnST, A. (1961 a): Mycobacterium tuberculosis H37Rv grown in vivo: Nature of the inhibitor of lactic dehydrogenase of Mycobacterium phlei. Proc. Soc. Exptl. Biol. Med., 106, 610-614.

ARtMAn, A. AND BeKIERKunst, A. (1961 b): Studies on Mycobacterium tuberculosis H37Rv grown in vivo. Am. Rev. Reps. Diseases, 83, 100-106.

Asaba, G., Nagatomi, H., Watabiki, S., Fukazawa, Y., Akiyama, T. amd Maeda, K. (1964a) : Passive transfer of immunity to tuberculosis by means of cells from BCG vaccinated mice. I. Kekkaku, 39, 55-59. (Text in Japanese with English summary)

Asaba, G., Nagatomi, H., Watabiki, S., Fukazawa, Y., Akiyama, T. And Maeda, K. $(1964 \mathrm{~b})$ : Passive transfer of immunity to tuberculosis by means of cells from BCG vaccinated mice. II. Kekkaku, 39, 95-99. (Text in Japanese with English summary)

Bastrrachea, F., Anderson, D. G. and Goldman, D. S. (1961) : Enzyme system in the mycobacteria. XI. Evidences for a functional glycolytic system. J. Bacteriol., 82, 94-105.

Beaconsfield, P., Ginsburg, J. And Kosinski, A. (1965): Glucose metabolism via the pentose phosphate pathway relative to cell replication and immunological response. Nature, 205, 50-52.

Bekierkunst, A. AND ARtMAN, M. (1959) : Effect of cell-free extracts from M. tuberculosis H37Rv on lung succinooxidase. Nature, 184, 458.

Bekierkunst, A. AND ARTMAN, M. (1960): Studies on Mycobacterium tuberculosis H37Rv grown in vivo: Inhibitor of lactic acid dehydrogenase in normal and infected mice. Proc. Soc. Exptl. Biol. Med., 105, 605-609.

Bekierkunst, A. AND ARTMAN, M. (1962): Tissue metabolism in infection. DPNase activity, DPN levels, and DPN-linked dehydrogenase in tissues from normal and tuberculous mice. Am. Rev. Resp. Diseases, 86, 832-838.

Bekierkunst, A., Artman, S. And Silman, N. (1964): Tissue metabolism in infection. Soluble nicotinamide-adenine dinucleotide in organs from tuberculous mice. Am. Rev. Resp. Diseases, 89, 575-578.

Berken, A. AND BenACERRAF, B. (1966): Properties of antibodies cytophilic for macrophages. J. Exptl. Med., 120, 119-144. 
Berthrong, M. AND Hamilton, M. A. (1959): Tissue culture studies on resistance in tuberculosis. II. Monocytes from normal and immunized guinea pigs infected with virulent human tubercle bacilli. Am. Rev. Tuberc., 79, 221-231.

BJERKEDAL, T. (1964) : Host-agent interaction in experimental tuberculosis in guinea pigs, with special reference to the effects of BCG vaccination. Am. J. Hyg., 79, 86-106.

Bladen, H. A., Evanc, R. T. And Mergenhagen, S. E. (1966) : Lesions in Eschericha coli membranes after action of antibody and complement. J. Bacteriol., 91, 2377-2381.

Bloch, H. (1950a) : Enzymatic characteristics of different mycobacteria. Am. Rev. Tuberc., 61, 207-271.

Bloch, H. (1950b) : Studies on the virulence of tubercle bacilli. Isolation and biological properties of a constituent of virulent organisms. J. Exptl. Med., 91, 197-218.

BLOCH, H. (1954): Intracellular survival of bacteria in acute chronic tuberculosis. Cellular Metabolism and Infections. Edited by E. Racker, Academic Press Inc., Publishers, New York.

Bloch, H., Widelock AND Peizer, L. R. (1953) : Susceptibility to sioniazid and pathogenicity of tubercle bacilli. Am. Rev. Tuberc., 68, 734-738.

Bloch, H. AND SEGAL, W. (1955): Viability and multiplication of vaccines in immunization against tuberculosis. Am. Rev. Tuberc., 71, 228-248.

Bloch, H., Defaye, J., Lederer, E. AND Noll, H. (1957) : Constituents of a " toxic-lipid" obtained from Mycobacterium tuberculosis. Biochem. Biophys. Acta, 23, 312-321.

Bouvier, C. A. AND BöHme, D. (1961) : Effects of killed tubercle bacilli (BCG) and constituents upon the reticuloendothelial system, the internal organs, and the distribution of circulating leucocytes of normal albino mice. Am. Rev. Resp. Diseases, 83, 85-95.

BOYDEN, S. V. (1964): Cytophilic antibody in guinea pigs with delayed type hypersensitivity. Immunology, 7, 474-483.

BOYden, S. V. AND SORKIN, E. (1960): The adsorption of antigen by spleen cells previously treated with antiserum in vitro. Immunology, 3, 272-283.

Bragg, P. D. AND Polglase, W. J. (1964): Enzymatic activities of streptomycin-dependent Escherichia coli in relation to valine formation. J. Bacteriol., 88, 1399-1402.

CARPENTER, R. R. AND BRANDRISS, M. W. (1964) : In vitro studies of cellular hypersensitivity and inhibition of cell migration by picrylated proteins. J. Exptl. Med., 120, 1231-1244.

Chaudhuri, S. N. AND Martin, S. P. (1953) : Effect of infection with $M$. tuberculosis and of tuberculin shock on the succinate dehydrogenase activity of guinea pig tissue. J. Exptl. Med., 98, 99-105.

Chaudhuri, S. N., Suter, N., Shah, N. S. ANd Martin, S. P. (1963) : Metabolism in infection: Study on the enzymatic damage in kidneys of guinea pig infected with $M y c o$ bacterium tuberculosis. J. Exptl. Med., 117, 71-79.

CoHn, Z. A. AND Morse, S. T. (1960): Functional and metabolic properties of polymorphonuclear leucocytes. I. Observations on the requirements and consequences of particle ingestion. J. Exptl. Med., 111, 667-687.

CoHn, Z. A. AND Wiener, E. (1963a) : The particulate hydrolases of macropphages. I. Comparative enzymology, isolation, and properties. J. Exptl. Med., 118, 991-1008.

COHN, Z. A. AND WIENER, E. (1963 b) : The particulate hydrolases of macrophages. II. Biochemical and morphological response to particle ingestion. J. Exptl. Med., 118, 1009-1020.

Colmn, M. L., Davis, C. L. AND MiddlebrooK, G. (1958) : Airborne immunization against tuberculosis. Science, 128, 1282-1283.

Colwell, C. A. AND Hess, A. R. (1963) : Mononuclear cells from animals of divergent susceptibility to tuberculosis. II. Antimycobacterial properties. Am. J. Resp. Diseases, 88, 47-54.

Consden, AND GlynN, L. E. (1955): Chemically identifiable bacterial residues in lung lesions. Lancet, No. 1, 943-945.

Consdeen, R. AND HowARD, A. (1957) : Improved method for detecting-diaminopimelic acid 
in lung lesions. J. Clin. Pathol., 10, 178.

Cornforth, J. S., Hart, P. D., Rees, R. J. W. And Stock, J. A. (1951) : Antituberculous effect of certain surface-active polyoxyethylene ethers in mice. Nature, 168, 150-153.

Costello, R. AND Dubos, R. J. (1965): Comparative vaccination studies in mice with BCG and mycobacteria killed by ethylene oxide. Japan-U. S. Cooperative Medical Science Program Abstracts. Leprosy and Tuberculosis Conference, May 18-20, Tokyo.

CROwle, A. J. (1958): Immunizing constituents of the tubercle bacillus. Bacteriol. Rev., 22, 183-203.

CROWLR, A. J. (1963) : Tubercle bacillary extracts immunogenic for mice. V. Specificity of tuberculo-immunity induced by trypsin extracts of tubercle bacilli. Tubercle, 44, 241-246.

Crowle, A. J. AND Teranuma, F. (1964): Tubercle bacillary extracts immunogenic for mice. VI. Comparative immunogenicity of trypsin extract of tubercle bacilli in mice and guinea pigs. Tubercle, 45, 40-50.

DANIEL, T. M. (1965): Observations on the antibody response of rabbits to mycobacterial antigens. J. Immunol., 95, 100-108.

DAvid, J. R. (1966): Delayed hypersensitivity in vitro: its mediation by cell-free substances formed by lymphoid cell-antigen interaction. Proc. Nat. Acad. Sci., U. S. A., 56, 72-77.

DAvid, J. R., LAwrence, H. S. AND Thomas, L. (1964a): Delayed hypersensitivity in vitro. III. The specificity of hapten-protein conjugates in the inhibition of cell migration. J. Immunol., 93, 279-282.

DAvid, J. R., LAwrence, H. S. AND Thomas, L. (1964 b) : The in vitro desensitization of sensitive cells by trypsin. J. Exptl. Med., 120, 1189-1200.

Debre, R., Noufflard, H., Brissaud, H. E. and Gerbeaux, J. (1959) : Infection of children by strains of tubercle bacilli initially resistant to streptomycin or to isoniazid. Am. Rev. Resp. Diseases, 80, 326-339.

DoI, R. H. AND IGARAsHI, R. T. (1964) : Relation of ribonucleic acid composition to growth rate and dormancy in Bacillus subtilis. Nature, 203, 1092-1094.

Dubos, R. J. (1954) : Biochemical Determinants of Microbiol Diseases. Harvard University Press, Cambridge, Massachusetts.

Dubos, R. J. (1955): Mechanisms of Microbial Pathogenicity, Cambridge University Press, Oxford, pp. 101-123.

Dubos, R. (1964): Acquired immunity to tuberculosis. The J. Burns Amberson lecture. Am. Rev. Resp. Diseases, 90, 505-515.

DubOs, R. J. AND HiRsch, J. G. (1954): The antimycobacterial activity of a peptide preparation derived from calf thymus. J. Exptl. Med., 99, 55-63.

Dubos, R. J. AND Middlerook, G. (1948) : Cytochemical reaction of virulent tubercle bacilli. Am. Rev. Tuberc. 58, 698-699.

Dubos, R. J. AND Schaedler, R. W. (1956): Reversible changes in the susceptibility of mice to bacterial infection. I. Change brought about by injection of pertussis vaccine or of bacterial endotoxins. J. Exptl. Med., 104, 53-66.

DuBOS, R. AND SchaEdLER, R. (1957): Effects of cellular constituents of mycobacteria on the resistance of mice to heterologous infection: I. Protective effect; II. Enhancement of infection. J. Exptl. Med., 106, 703-717.

Dumonde, D. C., Bitensky, L., Cunningham, G. J. And Chayen, J. (1965) : The effect of antibodies on cells. I. Biochemical and histochemical effects of antibodies and complement on acid tumor cells. Immunol., 8, 25-36.

EDA, T. (1964): Studies on the protein biosynthesis in mycobacteria. (II) Isolation and characterization of the ribosomes of BCG. Japan. J. Bacteriol., 19, 411-417. (Text in Japanese with English summary)

Elberg, S. S., Schneider, P. ANd Fong, J. (1957) : Cross-immunity between Brucella melitensis and Mycobacterium tuberculosis. Intracellular behavior of Brucella melitensis in monocytes from vaccinated animals. J. Exptl. Med., 106, 545-554. 
ElsBaCH, P. (1959) : Composition and synthesis of lipids in resting and phagocytizing leucocytes. J. Exptl. Med., 110, 969-980.

ENGELBERG, H. AND ARTMAN, M. (1961) : Effect of growth in limiting amounts of streptomycin on respiration and fermentation of a streptomycin-dependent mutant of $E$. coli. Biochem. Biophys. Acta, 47, 553-560.

ERIKSON, R. L. AND SMITH, D. W. (1962): Immunogenicity of defatted mycobacteria in guinea pigs. Am. Rev. Resp. Diseases, 85, 402-406.

Fauve, R. M., Pierce-Chase, C. H. ANd Dubos, R. (1964) : Corynebacterial pseudotuberculosis in mice. II. Activation of natural and experimental latent infections. J. Exptl. Med., 120, 283-304.

Fishman, M. AND AdLER, F. L. (1963) : Antibody formation initiated in vitro: II. Antibody synthesis in X-irradiated recipients of diffusion chambers containing nucleic acid derived from macrophages incubated with antigen. J. Exptl. Med., 117, 595-602.

Fong, J., Chin, D. AND ElBerG, S. S. (1963) : Studies of tubercle bacillus-histiocyte relationships. VI. Induction of cellular resistance by ribosomes and ribosomal RNA. J. Exptl. Med., 118, 371-386.

FonG, J., Chin, D. AND Vickrey, H. M. (1963) : Studies of tubercle bacillus-histiocyte relationships. VII. Homologous and heterologous transfer of cellular resistance. J. Exptl. Med., 118, 727-742.

Fong, J., SchNeIDER, P. AND ElBerG, S. S. (1957): Studies on tubercle bacillus-monocytes relationships. II. Induction of monocyte degeneration by bacteria and culture filtrate: Specificity of serum and monocyte effects on resistance to degeneration. J. Exptl. Med., 105, 25-37.

Fox, A. E., Evans, G. L., Turner, F. J., Schwartz, B. S. and Blaustein, A. (1966) : Stimulation of nonspecific resistance to infection by a crude cell wall preparation from $\mathrm{Myco}$ bacterium phlei. J. Bacteriol., 92, 1-5.

FREERKSEN, E. (1959): Deut. Med. Wochschr., 84, 1533-1540. Recited from Youmans, G. P. (1963) : The pathogenic "atypical" mycobacteria. Ann. Rev. Microbiol., 17, 473-494.

FREGNAN, G. B. AND SMITH, D. W. (1963) : Immunogenicity and allergenicity in guinea pigs of a defatted mycobacterial vaccine and its fractions. Am. Rev. Resp. Diseases, 87, 877-888.

FREUND, J. (1947): Some aspects of active immunization. Ann. Rev. Microbiol., 1, 291-308.

FRIEDMAN, R. M. (1964) : Inhibition of established tuberculin hypersensitivity by methotrexate. Prob. Soc. Exptl. Med., 116, 471-475.

FRIEDMAN, R. M. AND BUCKLER, C. E. (1963): Methotrexate inhibition of tuberculin hypersensitivity in inbred guinea pigs. J. Immunol., 91, 846-850.

Friedman, R. M., BUCKLleR, C. E. AND BARON, S. (1961): The effect of aminomethylpteroglutamic acid on the development of skin hypersensitivity and on antibody formation in guinea pigs. J. Exptl. Med., 114, 173-183.

FuKuI, Y., HiRAI, T., UCHIDA, T. AND YONEDA, M. (1965) : Extracellular proteins of tubercle bacilli. IV. $\alpha$ and $\beta$ antigens as major extracellular protein products and as cellular components of a strain (H37Rv) of Mycobacterium tuberculosis. Biken J., 8, 189-199.

Gangadharam, P. R. J., Cohn, M. L. AND MidDlebrooK, G. (1963) : Infectivity, pathogenicity and sulfolipid fraction of some Indian and British strains of tubercle bacilli. Tubercle, $44,452-455$.

Geronimus, L. H. AND Birkeland, J. M. (1951) : The relationship between the virulence of tubercle bacilli and the vigor of their oxidative attack upon certain substrate. Am. Rev. Tuberc., 64, 520-533.

Gottlieb, S. F., Rose, N. R., Maurizi, J. And LauphieR, E. H. (1964) : Oxygen inhibition of growth of Mycobacteria tuberculosis. J. Bacteriol., 87, 838-843.

GrogG, E. ANd Pearce, A. G. E. (1952): The enzymic and lipid histochemistry of experimental tuberculosis. Brit. J. Exptl. Pathol., 33, 567-576.

GuY, L. R., RAfFel, S. ANd Clifton, C. E. (1954): Virulence of the tubercle bacillus. II. 
Effects of oxygen tension upon growth of virulent and avirulent bacilli. J. Infect. Diseases, 94, 99-106.

Guze, L. B. And Kalmanson, G. M. (1964): Persistence of bacteria in "protoplast" form after apparent cure of pyelonephritis in rats. Science, 143, 1340-1341.

HANKs, J. H. AND GRAY, C. T. (1956): The metabolic properties of mycobacteria and the pathogenesis of mycobacterial disease. Advances in Tuberculosis Research, 7, 1-16.

HART, D. P. AND REES, R. J. W. (1960) : Effect of macrocyclon in acute and chronic pulmonary tuberculous infection in mice as shown by viable and total bacterial counts. Brit. J. Exptl. Pathol., 41, 414-421.

HAtTEN, B. A. AND Sulkin, S. E. (1966a): Intracellular production of Brucella L forms. I. Recovery of L forms from tissue culture cells infected with Brucella abortus. J. Bacteriol., 91, 285-296.

Hatten, B. A. AND Sulkin, S. E. (1966 b) : Intracellular production of Brucella L forms. II. Induction and survival of Brucella abortus L forms in tissue culture. J. Bacteriol., 91, $14-20$.

HEDGECOCK, L. W. (1964) : Resistance-enhancing activity of culture filtrates of Mycobacterium tuberculosis. J. Bacteriol., 88, 1349-1355.

Helper, J. Q., Clifton, C. E., Raffel, S. And Futrelle, C. M. (1954) : Virulence of the tubercle bacillus. I. Effects of oxygen tension upon respiration of virulent and avirulent bacilli. J. Infect. Diseases, 64, 90-98.

Higashikawa, M. (1960) : Studies on the immunological and biological properties of cell wall-, particle- and soluble-fractions isolated from BCG. Osaka Daigaku Igaku Zasshi, 12, 81-96. (Text in Japanese)

HiRsch, J. G. (1960a) : Antimicrobiol factors in tissues and phagocytic cells. Bacteriol. Rev., 24, 133-140.

Hirsch, J. G. (1960 b) : Further studies on preparation and properties of phagocytin. J. Exptl. Med., 111, 323-337.

Hirsch, J. G. (1962) : Cinemicrophotographic observations on granule lysis in polymorphonuclear leucocytes during phagocytosis. J. Exptl. Med., 116, 827-834.

Hirsch, J. G. (1965) : Phagocytosis. Ann. Rev. Microbiol., 19, 339-350.

Hobby, G. L., Lenert, T. F., Maier-Engallena, J., Wakely, C., Keblish, M., Manty, M. AND AUERBACH, O. (1966): Experimental tuberculosis and the immunogenic effect of BCG in germfree mice. Am. Rev. Resp. Diseases, 93, 396-410.

HoRN, R. G., SPICER, S. S. AdN Wetzel, B. K. (1964): Phagocytosis of bacteria by heterophil leucocytes. Am. J. Pathol., 45, 327-335.

Hoyer, J. R., Hoyer, L. W., Good, R. A. And Condie, R. M. (1962): The effect of 6mercaptopurine on delayed hypersensitivity in guinea pigs. J. Exptl. Med., 116, 679-685.

Hsu, H. S. (1965a) : In vitro studies on the interactions between macrophages of rabbits and tubercle bacilli. II. Cellular humoral aspects of acquired resistance. Am. Rev. Resp. Diseases, 91, 499-509.

Hsu, H. S. (1965b): In vitro studies on the interactions between macrophages of rabbits and tubercle bacilli. I. Cellular basis of native resistance. Am. Rev. Resp. Diseases, 91, 488-498.

Huempfaner, H. R. ANd Deuschle, K. W. (1966): Experimental tuberculosis in germ-free and conventional mice. Am. Rev. Resp. Diseases, 93, 465-467.

INDIRA, M. AND RAMAKRISCHNAN, T. (1963): Glucose dissimilation by Mycobacterium tuberculosis H37Rv. Am. Rev. Resp. Diseases, 88, 509-516.

INUI, A. (1963) : On the specificity in immunity for tuberculosis. II. Change in susceptibility of mice to bacterial endotoxin following infection with BCG or unclassified mycobacteria. Japan. J. Bacteriol., 18, 449-454. (Text in Japanese with English summary)

IsHikAWA, A. (1936): Die wasserstoffkonzentration der Leukozyten. Nagoya J. Med. Sci, $10,257-272$. 
Issaly, I. M., Issaly, A. AND Stoppani, A. O. M. (1961): Role of the pentose phosphate pathway in Pasteurella multocida. Nature, 191, 727-728.

JANICKI, B. W. AND PATNODE, R. A. (1961): Increase in circulating lysozyme-like enzyme following sensitization of guinea pigs with Mycobacterium tuberculosis. Am. Rev. Resp. Diseases, $83,872-877$.

Jesperson, A. AND BENTzON, M. W. (1964a): The acquired resistance to tuberculosis induced by BCG vaccine assayed by a quantitative method on red mice. I. Vaccination effect of BCG strains strongly or weakly virulent for hamsters. Acta Tuberc. et Pneumol. Scand., $X L I V, 253-266$.

Jesperson, A. AND Bentzon, M. W. (1964 b) : The acquired resistance to tuberculosis induced by BCG vaccine assayed by a quantitative method on red mice. II. Vaccination effect of BCG strains strongly or weakly virulent for hamsters. Acta Tuberk. et Pneumol. Scand., XLIV, 276-289.

KANAI, K. (1963): Growth-inhibition phenomenon by glucose in relation to the virulence of tubercle bacilli. Kekkaku, 38, 224-229. (Text in Japanese with English summary)

KANAI, K. (1964): Change of acid phosphatase activity of the liver and the spleen in experimental mouse tuberclosis. Kekkaku, 39, 112-116. (Text in Japanese with English summary)

KANAI, K. (1966 a) : Experimental studies on host-parasite equilibrium in tuberculous infection, in relation to vaccination and chemotherapy. Japan. J. Med. Sci. Biol., 19, 181-199.

KANAI, K. (1966 b) : Studies on subculture medium to maintain the virulence of Mycobacterium tuberculosi (Strain H37Rv). Kekkaku, 41, 467-472. (Text in Japanese with English summury)

KANAI, K. (1967 a) : Detection of host-originated acid phosphatase on the surface of " in vivo grown tubercle bacilli". Japan. J. Med. Sci. Biol., 20, 73-90.

KANAI, K. (1967 b) : Resistance to sodium hydroxide of "in vivo grown tubercle bacilli". Japan. J. Med. Sci. Biol., 20, 91-96.

KANAI, K. AND YANAGISAWA, K. (1955) : Studies on the reinfection in experimental tuberculosis in guinea pigs. Japan. J. Med. Sci. Biol., 8, 115-127.

KANAI, K. AND YOUMANS, G. P. (1960): Immunogenicity of intracellular particles and cell walls from Mycobacterium tuberculosis. J. Bacteriol., 80, 607-614.

Kanai, K., Katsuyama, S. And Yanagisawa, K. (1955): An interference phenomenon between virulent and avirulent tubercle bacilli concerning their multiplication and survival in guinea pigs, with special reference to the mechanism of virulence-enhancement of mycobacterial strains by animal passage. Japan. J. Med. Sci. Biol., 8, 207-218.

KanaI, K., Wiegeshaus, E. AND Smith, D. W. (1965): Detection of lipids of in vitro grown mycobacteria in bacilli separated from infected tissues. Report in Kolloquium im Forschungsinstitute Borstel über die Variabilität der Mycobakterien unter experimentellen und klinischen Bedingungen. Am. 13, 14 und 15. Oktober 1965.

KanaI, K., Wiegeshaus, E. AND Smith, D. W. (1966) : Effect of methotrexate on delayed sensitivity and immunity in experimental airborne tuberculosis. Am. Rev. Resp. Diseases, 93, 754-757.

KANAI, K., Youmans, G. P. AND Youmans, A. S. (1960): Allergenicity of intracellular particles, cell walls, and cytoplasmic fluid from Mycobacterium tuberculosis. J. Bacteriol., $80,615-621$.

KARLSON, A. G. (1665): Maintenance of the pathogenicity of Mycobacterium tuberculosis (strain H37Rv) for guinea pigs during a 20-year period. Presented at the 18th International Tuberculosis Conference, Munich. Session IV, Thursday, October 7.

KARNOvSKy, M. L. (1962): Metabolic basis of phagocytic activity. Physiol. Rev., 42, 143-168.

KARnovsky, M. L. AND Wallach, D. F. H. (1961): The metabolic basis of phagocytosis. III. Incorporation of inorganic phosphate into various classes of phosphatides during phagocytosis. J. Biol. Chem., 236, 1895-1901. 
Kato, M. (1966 a) : Studies on the biochemical lesion in experimental tuberculosis in mice. I. Effect of cord factor on the succinate-neotetrazolium reductase system. Am. Rev. Resp. Diseases, 93, 411-420.

KATO, M. (1966 b) : Effect of tubercle bacilli and toxic bacterial constituent on respiratory metabolism in host-cell. U. S.-Japan Cooperative Medical Science Program. Leprosy and Tuberculosis Conference, Tokyo, May 18-20.

KATO, M. (1966c): Studies on the biochemical lesion in experimental tuberculosis in mice. II. Bacterial constituents responsible for the inhibition of the succinate-neotetrazolium reductase system. Am. Rev. Resp. Diseases, 93, 421-427.

Kato, M., Miki, K., Matsunaga, K. And Yamamura, Y. (1958) : Biologic biochemical activities of cord factor with special reference to its role in the virulence of tubercle bacilli. Am. Rev. Tuberc., 77, 482-491.

Kato, M., Miki, K., Matsunaga, K. And Yamamura, Y. (1959 b) : Biochemical analysis of the virulence of tubercle bacilli. Am. Rev. Tuberc., 80, 535-542.

Kato, M., Kusunose, M., Miki, K., Matsunaga, K. And Yamamura, Y. (1959 a): The mechanism of the toxicity of cord factor. Am. Rev. Tuberc., 80, 240-248.

KHoO, K. K. AND MACKANEss, G. B. (1964) : Macrophage proliferation in relation to acquired cellular resistance. Australian J. Exptl. Biol. Med. Sci., 42, 707-716.

Kishimoto, Y., Akiyama, T. AND Ushiba, D. (1964): Studies on the relation between duration of immunity and persistence of avirulent bacilli in experimental typhoid. An experiment using a streptomycin-dependent strain for immunization. Reported in General Meeting of Kanto District of Japan Bacteriological Association. October 10 and 11, Tokyo.

Klugh, G. A. AND PRATt, P. C. (1962) : Experimental immunization of guinea pigs with photochromogenic acid-fact bacilli. Am. Rev. Resp. Diseases, 85, 78-83.

Knox, R., Meadow, P. M. AND Worssam, A. R. H. (1956): The relation between the catalase activity, hydrogen peroxide sensitivity, and isoniazid resistance of mycobacteria. Am. Rev. Tuberc., 73, 726-734.

Knox, R., Thomas, C. G. A., Lister, A. J. And Saxby, C. (1961): The effect of oxygen on the growth of Mycobacterium tuberculosis in semi-solid agar. Guy's Host. Rept., 110, $174-180$.

Kotani, S., Kitaura, T., Hirano, T. And Tanaka, A. (1959): Isolation and chemical composition of the cell walls of BCG. Bicken's J., 2, 129-141.

KoYAMA, K. (1964) : Experimental studies on immunizing effect of unclassified acid-fast bacilli against tuberculous infection. I. Kekkaku, 39, 64-68. (Text in Japanese with English summaro)

KoYAMA, K. (1965): Experimental studies on immunizing effect of unclassified mycobacteria against tuberculous infection. II. Kekkaku, 40, 295-301. (Text in Japanese with English summary)

Kusaka, T., Sato, R. ANd ShojI, K. (1964): Comparison of cytochromes in mycobacteria grown in vitro and in vivo. J. Bacteriol., 87, 1383-1388.

LARSON, C. L. AND RIBI,, E. (1966): Studies on protoplasms of acid-fast bacilli provoking delayed reactions in sensitized guinea pigs and rabbits. Japan-U.S. Cooperative Medical Science Program. Leprosy and Tuberculosis Conference, May 18-20, Tokyo.

LARSON, C. L. AND WICHT, W. C. (1962): Studies of resistance to experimental tuberculosis in mice vaccinated with living attenuated tubercle bacilli and challenged with virulent organisms. Am. Rev. Resp. Diseases, 85, 833-846.

LARSON, C. L. AND WICHT, W. C. (1963): Resistance to infection with virulent tubercle bacilli in mice immunized with viable Mycobacterium balnei and unclassified mycobacteria administered aerogenically. Am. Rev. Resp. Diseases, 88, 456-461.

LARSON, C. L. AND WICHT, W. C. (1964) : Infection of mice with Mycobacterium tuberculosis, strain H37Ra. Am. Rev. Resp. Diseases, 90, 742-748.

LARson, C. L., Ribi, E., Wicht, W. C. AND List, R. (1961): Skin reactions produced in 
rabbits by cell walls and protoplasm of Mycabacterium tuberculosis and M. butyricum. Am. Rev. Resp. Diseases, 83, 184-193.

Larson, C. L., Ribi, E., Wicht, W. E., List, R. H. AND Good, G. (1963) : Resistance to tuberculosis in mice immunized with BCG disrupted in oil. Nature, 198, 1214-1215.

LEAKE, E. S. AND MYRVIK, Q. N. (1964): Differential release of lysozyme and acid phosphatase from subcellular granules of normal rabbits alveolar macrophages. Brit. J. Exptl. Pathol., 45, 384-392.

LeAKe, E. S., Gonzales-OjedA, D. AND MYrvik, Q. N. (1964): Ezymatic differences between normal alveolar macrophages and oil-induced preitoneal macrophages obtained from rabbits. Exptl. Cell Res., 33, 553-561.

LEBEK, G. (1959) : Die Abhängigheit der Sauerstoff Optimums der beiden säugetier Typen des Mycobacterium tuberculosis von der angebotenen Nährstoffen. Zentr. Bakteriol. I Orig., $176-178$ and $530-537$.

LOCKWOOD, W. R. AND ALlisON, F (1963): Electronmicrographic studies of phagocytic cells. I. Morphologic changes in the cytoplasm and granules of rabbit granulocytes associated with ingestion of rough pneumococci. Brit. J. Exptl. Pathol., 44, 593-600.

LOckwoOD, W. R. AND AlLISON, F. (1964) : Electronmicrographic studies of phagocytic cells. II. Observations on the changes induced in the cytoplasmic contents of human granulocytes by the ingestion of rough pneumococcus. Brit. J. Exptl. Pathol., 45, 294-299.

LOVELOCK, J. E. AND REES, R. J. W. (1955) : Possible site and mode of action of certain lipotropic macromolecules in tuberculosis. Nature, 175, 161-163.

LURIE, M. B. (1942): Studies on the mechanism of immunity in tuberculosis. The fate of tubercle bacilli ingested by mononuclea phagocytes derived from normal and immunized animals. J. Exptl. Med., 75, 247-268.

LURIE, M. B. (1964) : Resistance to Tuberculosis. Experimental studies in Native and Acquired Defensive Mechanisms. Harvard University Press, Cambridge, Massachusetts.

Lyon, R. H., Lichstein, H. L. ANd HaLl, W. H. (1961): Factors affecting the growth of Mycabacterium tuberculosis in aerobic and stationary cultures. Am. Rev. Resp. Diseases, 83, 255-260.

MACKANESS, G. B. (1954) : The growth of tubercle bacilli in monocytes from normal and vaccinated rabbits. Am. Rev. Tuberc., 69, 495-504.

MACKANESS, G. B. (1964): The immunological basis of acquired cellular resistance. J. Exptl. Med., 120, 105-120.

Mackaness, G., B., Smith, N. AND Wells, A. Q. (1954): The growth of intracellular tubercle bacilli in relation to their virulence. Am. Rev. Tuberc., 69, 479-494.

Maeda, K., ARima, J. And Yamamoto, K. (1964): The effect of aminopterin and 6-mercaptopurine on experimental tuberculosis. Ann. Meeting Jap. Tuberc. Soc., April, Tokyo.

Martin, S. P., Cooper, C. D., Chaudhuri, S. N. AND Green, R. (1955): A tissue factor influencing succinic dehydrogenase activity in tuberculous guinea pigs. J. Exptl. Med., 101, 639-646.

Matsuura, Y., Oka, Y. AND Yoshioka, T. (1960): Studies on prevention of infection. New approaches for the preparation of effective vaccines. Sogoigaku, 17, 33-40. (Text in Japanese)

Mattman, L. H., Tunstall, L. H., Mathews, W. W. and Gordon, D. L. (1960) : L forms in mycobacteria. Am. Rev. Resp. Diseases, 82, 202-211.

MCCUne, R. M. Jr. AND TOMSETT, R. (1956) : Fate of Mycobacterium tuberculosis in mouse tissues as determined by microbiol enumeration technique. I. The persistence of drug-susceptible tubercle bacilli in the tissues despite prolonged antimicrobial therapy. J. Exptl. Med., 104, 737-762.

MCCune, R' M. Jr., Feldman, F. M. AND MCDeRmott, W. (1966) : Microbial persistence. II. Characteristics of the sterile state of tubercle bacilli. J. Exptl. Med., 123, 469-486.

McCune, R. M., Jr., Tomsetr, R. And McDermott, W. (1956) : Fate of Mycobacterium 
tuberculosis in mouse tissues as determined by microbial enumeration technique. II. The conversion of tuberculous infection to the latent state by the administration of pyrazinamide and a companion drug. J. Exptl. Med., 104, 763-802.

McCune, R. M. Jr., Feldman, F. M., Lambert, H. P. And McDermott, W. (1966) : Microbial persistence. I. The capacity of tubercle bacilli to survive sterilization in mouse. J. Exptl. Med., 123, 445-468.

MCDERMOTt, W. (1958) : Microbiol persistence. Yale J. Biol. Med., 30, 257-291.

McDermott, W. (1962) : The J. Burns Amberson Lecture. The chemotherapy of tuberculosis. Am. Rev. Resp. Diseases, 86, 323-335.

MeIssneR, G. (1956) : Isoniazid-resistante Tuberkelbakterien. Advances in Tuberculosis Research, 7, 52-100.

Merckx, J. J., Brown, A. L. And Karlson, A. G. (1964) : An electronmicroscopic study of experimental infections with acid-fast bacilli. Am. Rev. Resp. Diseases, 89, 485-496.

MiddlebrooK, G. (1961): Immunological aspects of airborn: infection: Reactions to inhaled antigens. Bacteriol. Rev., 25, 331-346.

MiddlebrooK, G. (1965) : Bacterial and Mycotic Infections of Man. 4th Ed., J. B. Lippincott Company, Philadelphia and Montreal.

Middlebrook, G. AND CoHn, M. L. (1953) : Some observations on the pathogenicity of isoniazid-resistant variants of tubercle bacilli. Science, 118, 297-299.

MiddlebrooK, G., Coleman, C. M. ANd Schaefer, W. B. (1959) : Sulfolipid from virulent tubercle bacilli. Proc. Nat. Acad. Sci., U. S. A, 45, 1801-1804.

Middlebrook, G., Dubos, R. J. ANd Pierce, C. (1947) : Virulence and morphological characteristics of mammalian tubercle bacilli. J. Exptl. Med., 86, 175-184.

Miki, K. And Mackaness, G. B. (1964): The passive transfer of acquired resistance to. Listeria monocytogenes. J. Exptl. Med., 120, 93-103.

Mirllman, I. (1962) : Passive transfer of resistance to tuberculosis. Am. Rev. Resp. Diseases, 85, 30-32.

Millman, I. AND Youman, G. P. (1955): The characterization of the terminal respiratory enzymes of the H37Ra strain of Mycobacterium tuberculosis var hominis. J. Bacteriol., 69, 320-325.

MryagawA, M. AND Kishimoto, H. (1962): Infection of bacteria-free animals with tubercle bacilli. Kekkaku, 37, 332-337. (Text in Japanese)

MotomiYA, M. and KAYABA, S. (1956) : Über die einflüsse des Heterosates auf BCG-imphschutz. Japan. J. Tuberc., 8, 42-52.

Moulder, J. W. (1948): The oxidative metabolism of Trypanosoma lewisi in a phosphatesaline medium. J. Infect. Diseases, 83, 33-49.

Murohashi, T. AND YoshidA, K. (1966) : Relation between the loss of acid-fastness due to. ultraviolet irradiation and the pathogenicity of tubercle bacilli. Am. Rev. Resp. Diseases, 94, 86-93.

MUSCHEL, L. H. AND JACKSON, J. E. (1966) : Reversal of the bactericidal reaction of serum by magnesium ion. J. Bacteriol., 91, 1399-1402.

MyrviK, Q. N., LeAKe, E. S. AND FARISS., B. (1961): Lysozyme content of alveolar and peritoneal macrophages from the rabbit. J. Immunol., 86, 133-136.

MYrvik, Q. N., LeAKe, E. S. AND Oshima, S. (1962) : A study of macrophages and epitheloid-like cells from granulomatous (BCG-induced) lungs of rabbits. J. Immunol., 89, 745-751.

MYRVIK, Q. AND WeISER, R. S. (1951): A tuberculostatic serum substance possesing lysozymelike properties. Am. Rev. Tuberc., 64, 669-674.

MYrviK, Q., WEISER, R. S. AND AGAR, H. D. (1953) : Lethal and cytologic effects of lysozyme on tubercle bacilli. Am. Rev. Tuberc., 67, 217-231.

Nagasuga, T., Terai, T. And Yamamura, Y. (1961): Studies on the toxic lipid of isoniazid-resistant human tubercle bacill!. Am. Rev. Resp. Diseases, 83, 248-254.

Nelson, D. S. And Boyden, S. V. (1963): The loss of macrophages from peritoneal exudates 
following the injection of antigens into guinea pigs with delayed hypersensitivity. Immunology, $6,264-275$.

Nemoto, I., Akiyama, T., Ushiba, T., Nagatomi. H., Watanuki, Y. and Asaba, H. (1964): The effect of 6-mercaptopurine on the development of serum antibodies, tuberclin hypersensitivity and protective immunity in BCG vaccinated guinea pigs. Ann. Meeting Jap. Tuberc. Soc., April, Tokyo. (In Japanese)

NiffeneGger, J. AND Youmans, G. P. (1960): The effect of macrocyclon on the multiplication of tubercle bacilli in the lungs and spleen of mice. Brit. J. Exptl. Pathol., 41, 403-413.

Nishihara, H., Lawrence, C. A., Taplin, G. V. And Carpenter, C. M. (1963) : Immunogenicity of gamma-iradiated Mycobacterium tuberculosis H37Rv (GIV) in mice. Am. Rev. Resp. Diseases, 88, 827-832.

Noll, H., Bloch, H., Asselineau, J. And Lederer, E. (1956): The chemical structure of the cord factor of Mycobacterium tuberculosis. Biochem. Biophys. Acta, 20, 299-309.

NoRTH, R. J. AND MACKANESS, G. B. (1963 a): Electronmicroscopical observations on the peritoneal macrophages of normal mice and mice immunized with Listeria monocytogenes. I. Structure of normal macrophages and the early cytoplasmic response to the presence of ingested bacteria. Brit. J. Exptl. Pathol., 44, 901-607.

NORTH, R. J. AND MACKANSS, G. B. (1963 b): Electronmicroscopical observations on the peritoneal macrophages of normal mice and mice immunized with Listeria monocytogenes. II. Structure of macrophages from immune mice and early cytoplasmic response to the presense of ingested bacteria. Brit. J. Exptl. pathol., 44, 608-611.

Novy, G. F. AND, Soule, M. H. (1925): Microbic respiration. II. Respiration of the tubercle bacillus. J. Infact. Diseases, 36, 168-232.

NUKADA, S. AND RYU, C. (1936) : Ueber Schwankungen der Resistenz gegen tödlich haematogene Tuberkelbazilleninfektion nach Immunisierung mit Heterobakterien. 2. Immunitätsforsch., $88,496-508$.

NUKADA, S. AND Utsunomiya, S. (1956): Eine methods zur Bestimmung der resistenzsteigernden Wirkung gegen tuberkulöse Infektion an Mäusen. Z. Immunitätsforsch., 113, 375-378.

NYKA, W. (1956): Enhancement of resistance to tuberculosis in mice experimentally infected with Brucella abortus. Am. Rev. Tuberc., 73, 251-265.

NykA, W. (1963): Studies on Mycobacterium tuberculosis in lesions of the human lung. Am. Rev. Resp. Diseases, 88, 670-679.

Ohren, R., Farnham, A. E., Saito, K., Milofsky, E. and Karnovsky, M. C. (1963) : Metabolic patterns in three types of phagotizing cells. J. Cell Biol., 17, 487-501.

Orskav, J. (1964): The acid-fastness of bacilli and the cytoplasmic membrane. Acta Path. Microbiol. Scand., 61, 453-456.

Oshima, S., Myrvik, Q. N. AND LeAKe, E. (1961): The demonstration of lysozyme as a dominant tuberculostatic factor in extracts of granulomatous lungs. Brit. J. Exptl. Pathol., 42, 138-144.

Palmer, C. E. AND Hopwood, L. (1962) : Bull. Intern. Union Against Tuberc., 32, 398402. Recited from Youmans, G. P. (1963) : The pathogenic "atypical" mycobacteria. Ann. Rev. Microbiol., 17, 473-494.

Patnode, R. A., Wrinkle, C. K. And Beasley, C. (1954): Evaluation of the oxidationreduction dye test for the determination of virulence of mycobacteria in vitro. Am. Rev. Tuberc., 69, 599-603.

Pierce, C. H., Dubos, R. J. And Schaefer, W. B. (1953): Multiplication and survival of tubercle bacilli in the organs of mice. J. Exptl. Med., 97, 189-205.

Pierce-Chase, C. H., Fauve, R. M. And Dubos, R. (1964) : Corynebacterial pseudotuberculosis in mice. I. Comparative susceptibility of mouse strains to experimental infection with Corynebacterium kutscheri. J. Exptl. Med., 120, 267-281.

Pinner, M. (1945): Pulmonary Tuberculosis in the Adult, Charles C Thomas, Springfield, 
Illinois.

PokornÝ, J. (1962) : Cultivation of mycobacteria in vivo: II. Study of cellular lipids. Rozhl. Tuberk., 22, 511-517. (Text in Czech).

PokORnÝ, J. AND ŠulovÁ, J. (1962) : Cultivation of mycobacteria in vivo. Rozhl. Tuberk., 22, 241-247. (Text in Czech).

Prickard, R. W. AND HAYES, D. W. (1961): The effect of aminopterine on guinea pig tuberculosis. Am. J. Pathol., 38, 325-333.

RAfFel, S. (1956): Immunopathology of tuberculosis. Am. Rev. Tuberc. (Supp.) 74, 60-74.

RAMAKRISHNAN, T., INDIRA, M. AND MALLER, R. K. (1962) : Evaluation of the routes of glucose utilization in virulent and avirulent strains of $M$. tuberculosis. Biochem. Biophys. Acta, 59, 529-532.

RAMSEIER, H. AND SUTER, E. (1964 a): An anti-mycobacterial principle of peritoneal mononuclear cells. I. The inhibition of tubercle bacilli by disrupted mononuclear cells obtained from normal and BCG-immunized guinea pigs. J. Immunol., 93, 511-517.

RAMSEINER, H. AND SuTER, E. (1964 b) : An anti-mycobacterial principle of peritoneal mononuclear cells. II. Properties and intracellular location of the antimycobacterial principle found in giinea pig mononuclear cells. J. Immunol., 93, 518-523.

REES, R. J. W. AND HART, D. P. (1961): Analysis of the host-parasite equilibrium in chronic murine tuberculosis by total and viable bacillary counts. Brit. J. Exptl. Pathol., 42, 83-88.

RIBI, E. AND LARSON, C. (1964): Immunological properties of cell wall versus protoplasm from mycobacteria. Zentralblatt für Bakteriologie I. Referate, 194, 673-685.

Ribi, E., BREhMer, W. AND MILNER, K. (1966): Specificity of resistance to tuberculosis and salmonellosis stimulated in mice by oil-treated cell walls. Proc. Soc. Exptl. Biol. Med., in press.

Ribi, E., Anacker, R. L., Brehmer, W., Goode, G., Larson, C. L., List, R. H., Milner, K. C. AND WICHT, W. (1966): Some factors influenciag protiction against experimental tuberculosis in mice by heat-stable cell-wall vaccines. J. Bacterial., in press.

RiBI, E., LARSON, C. L., LIST, R. AND WICHT, W. (1958): Immunologic significance of the cell wall of mycobacteria. Proc. Soc. Exptl. Biol. Med., 98, 263-265.

Ribi, E., Larson, C. L., Wicht, W., List, R. AND Goode, G. (1965) : Resistance to experimental tuberculosis stimulated by fractions from attenuated tubercle bacilli. Proc. Soc. Exptl. Biol. Med., 118, 926-933.

Ribi, E., LARson. C., Wicht, W., List, R. AND GOOD, G. (1966) : Effective nonliving vaccine against experimental tuberculosis in mice. J. Bacteriol., 91, 975-983.

Ribi, E., PERrine, T., List, R., Brown, W. AND GoOD. G. (1959) : Use of pressure cell to prepare cell walls from mycobacteria. Proc. Soc. Exptl. Biol. Med., 100, 647-649.

RICH, A. R. (1951): The Pathogenesis of Tuberculosis, Charles C Thomas, Publisher, Springfield, Ill.

Rist, N. (1951) : Le pouvoir pathogéne et allergisant des bacilles tuberculeux morts enrobés dans l'huile de paraffine. Advances in Tuberculosis Research, 4, 219-235.

Robson, J. M. AND Smith, J. T. (1961): Multiplication of Mycobacterium tuberculosis in the lungs and its modification by immunity and by chemotherapy. Am. Rev. Resp. Diseases, 84, $818-823$.

Robson, J. M., Smith, J. T. AND Thomas, C. G. A. (1960) : Multiplication of Mycobacterirum tuberculosis in the cornea and its modification by immunity and by isoniazid. Am. Rev. Resp. Diseases, 82, 195-201.

Rossi, F. AND ZATti, M. (1961) : Pathway of glucose oxidation in leucocytes. Experimental Cell Research, 25, 182-183.

Rossi, F. AND ZATTI, M. (1964): Changes in the metabolic pattern of polymorphonuclear leucocytes during phagocytosis. Brit. J. Exptl. Pathol., 45, 548-559.

Rous, P. (1925 a) : The relative reaction within living mammalian tissues: I. General features of vital staining with litmus. J. Exptl. Med., 41, 379-397. 
Rous, P. (1925 b) : The relative reaction within living mammalian tissues : II. On the mobilization of acid material within cells and the reaction as influenced by the cell state. J. Exptl. Med., 41, 399-410.

Rowley, D. (1955) : Stimulation of natural immunity to infections. Observations on mice. Lancet, 1, 232-234.

Rowlsy, D. (1956) : Rapidly induced changes in the level of non-specific immunity in laboratory animals. Brit. J. Exptl. Pathol., 37, 223-234.

Rowley, D. (1962) : Phagocytosis. Adv. Immunol., 2, 241-264.

SAITO, K. AND SUTER, E. (1965): Lysosomal acid hydrolases in mice infected with BCG. J. Exptl. Med., 121, 727-738.

SALTON, M. R. J. AND HoRNE, R. W. (1951): Studies on the bacterial cell wall. II. Methods of preparation and some properties of cell walls. Biochem. Biophys. Acta, 7, 177-197.

SANTER, M. AND AJL, S. (1955 a): Metabolic reactions of Pasteurella pestis. I. The fermentation of glucose. J. Bacteriol., 69, 298-302.

SANTER, M. AND AJL, S. (1955 b) : Metabolic reactions of Pasteurella pestis. II. The hexose monophosphate shunt in the growth of pasteurella pestis. J. Bacteriol., 69, 713-718.

SATAKE, O. (1963) : Studies on unclassified mycobacteria. II. Immunogenicity of unclassified mycobacteria. Sci. Rep. Res. Inst. Tohoku Univ., 11, 176-186.

SATO, I. AND MitsuhashI, S. (1966) : Experimental Salmonellosis. VII. In vitro transfer of cellular immunity by ribosomal fraction of mouse mononuclear phagocytes. J. Bacteriol. 90, 1194-1199.

SBARRA, A. J. AND KARNOVsky, M. L. (1959): The biochemical basis of phagocytosis. I. Metabolic changes during the ingestion of particles by polymorphonuclear leukocytes. J. Biol. Chem., 234, 1355-1362.

SEGAL, W. (1965 a) : Comparative study of in vivo and in vitro grown Mycobacterium tuberculosis. IV. Immunologic differentiation. Proc. Soc. Exptl. Biol. Med., 118, 214-218.

SEGAL, W. (1965 b) : Comparative study of mycobacterium grown in vivo and in vitro. V. Differences in staining properties. Am. Rev. Resp. Diseases, 91, 285-287.

SEgAL, W. AND Bloch, H. (1956): Biochemical differentiation of $M$. tuberculosis grown in vivo and in vitro. J. Bacteriol., 72, 132-141.

Segal, W. AND Bloch, H. (1957): Pathologic and immunologic differentiation of $M$. tuberculosis grown in vitro and in vivo. Am. Rev. Tuberc., 75, 495-500.

SEver, J. L. (1960) : Passive transfer of resistance to tuberculosis through use of monocytes. Proc. Soc. Exptl. Biol. Med., 103, 326-329.

SEver, J. L. AND Youmans, G. P. (1957 a): The relation of oxygen tension to virulence of tubercle bacilli and to acquired resistance in tuberculosis. J. Infect. Diseases, 101, 193-202.

SEVER, J. L. AND Youmans, G. P. (1957 b) : The enumeration of nonpathogenic viable tubercle bacilli from the organs of mice. Am. Rev. Tuberc., 75, 280-294.

SheEHAN, H. L. AND Whitewell, F. (1949) : The staining of tubercle bacilli with sudan B. J. Pathol. Bacteriol., 61, 266, 1949.

SHILO, M. (1959): Nonspecific resistance to infections. Ann. Rev. Microbiol., 13, 255-278.

SHIMOIDE, H. (1960): Experimental studies on airborne infection of tubercle bacilli. Report II. The effect of BCG vaccination on airborne infection in guinea pigs. Kekkaku, 35, 570575. (Text in Japanese with English summary)

SiEBNMANN, C. O. AND BARBARA, C. (1964): Immunologic relationship between typical and atypical mycobacteria as studied by means of the mouse protection test. Am. Rev. Resp. Diseases, 89, 20-28.

SMADEL, J. E. (1963) : Intracellular infections. Bull. N. Y. Acad. Med., 39, 158-172.

SMITH, D. W. (1962): Conference or Immunity and Pathogenesis of Mycobacteria Diseases, U. S. National Institutes of Health, March, Washington.

SMITH, D. W. AND RoBeRTson, J. A. (1962) : Immunogenicity in guinea pigs of lipid fractions of Mycobacterium tuberculosis. Am Rev. Resp. Diseases, 85, 398-401. 
Smith, D. W., Fregnan, G. B., De Laquerriere-Richardson, L. ANd Valdivia, E. (1964): Induction of acquired resistance in guinea pigs with defatted Mycobacterium tuberculosis vaccines. J. Bacteriol., 88, 87-92.

Smith, D. W., Wiegeshaus, E., Navalkar, R. And Grover, A. A. (1966) : Host-parasite relationships in experimental airborne tuberculosis. I. Preliminary studies in BCG-vaccinated and nonvaccinated animals. J. Bacteriol., 91, 718-724.

SPITZNAGEL, J. K. AND CHI, H. Y. (1963) : Cationic proteins and antibacterial properties of infected tissues and leukocytes. Am. J. Pathol., 43, 697-711.

StÄHElin, H., SutER, E. AND KARNOvSKy, M. L. (1956): Studies on the interaction between phagocytes and tubercle bacilli. I. Observations on the metabolism of guinea pig leucocytes and the influence of phagocytosis. J. Exptl. Med., 104, 121-136.

SteEnken, W. (1946): History of H37Ra strain of tubercle bacilli. Am. Rev. Tuberc., 54, 62-66.

STÖSS, B. AND HERRMANN, R. (1965): Immunogenic activity of lipids of M. tuberculosis. Nature, 208, 1224.

SugiharA, P. T., Brosbe, E. A. AND Smith, C. R. (1965) : Effect of hyperimmune rabbit serum on intracellular growth of Mycobacterium bovis. Proc. Soc. Exptl. Biol. Med., 120, 333-336.

Sudey, T. E. AND Hartsell, S. E. (1963) : Lipids and lysozymic lysis of achromobactor. J. Bacteriol., 85, 1174-1175.

SuTE, E. (1953): Multiplication of tubercle bacilli within mononuclear phagocytes in tissue cultures derived from normal animals and animals vaccinated with BCG. J. Exptl. Med., 97, 235-245.

Suter, W. E. AND Dubos, R. J. (1951): Variability of BCG strain (Bacillus Calmette Guerin). J. Exptl. Med., 93, 559-572.

Suter, E. AND Hulliger, L. (1960): Nonspecific and specific cellular reactions to infections. Ann. N. Y. acad. Sci., 88, 1237-1245.

TAliaferro, W. H. AND PIzzI, T. (1960): The influence of nucleic acid and protein synthesis in Trypanosoma lewisi by the antibody ablastin. Proc. Nat. Acad. Sci., 46, 733-745.

TANAKA, A. (1966): Purification and characterization of an adjuvant-active mycobacterial lipid. Japan-U. S. Cooperative Medical Science Program Abstracts. Leprosy and Tuberculosis Conference, May 18-20. Tokyo.

Terai, T. AND NAgAsuga, T. (1962): The correlation between the infecting doses of tubercle bacilli and the survival curve of mice in experimental tuberculosis. Kekkaku, 37, 283-286. (Text in Japanese with English summary)

Terai, T. AND NAgasuga, T. (1963) : Effect of constituents of mycobacteria on the resistance of experimental animals against tuberculous infection. Kekkaku, 38, 159-165. (Text in Japanese with English summary)

ThacoRe, H. AND Willett, H. P. (1963): Formation of spheroplasts of Mycobacterium tuberculosis by lysozyme. Proc. Soc. Exptl. Biol. \& Med., 114, 43-46.

THACORE, H. AND Willett, H. P. (1966): The formation of spheroplasts of Mycobacterium tuberculosis in tissue culture cells. Am. Rev. Resp. Diseases, 93, 786-791.

Thorbecke, G. J., Old, L. J., Benacaraf, B. And Clarke, D. A. (1961) : A histochemical study of acid and alkaline phosphatase in mouse livers during various conditions modifying activity of the reticuloendothelial system. J. Histochem. Cytochem., 9, 392-399.

TOYOHARA, M. AND SHImOIDE, H. (1964): The effect of superinfection with photochromogenic mycobacteria in the evolution of tuberculosis in experimental animals. Japan. J. Tuberc., 12, 77-84.

TSUCHIYA, K. AND YAMAZAKI, T. (1964): Studies on the heterologous immunogenicity of mycobacterial cells. II. Separation of the heterologous immunogenic substance from BCG cells. Japan. J. Bacteriol., 20, 1-4. (Text in Japanese with English summary)

Tsumita, T., Aoyagi, T., Matsumoto, R., Kondo, E., Mizuno, D. and Takahashi, H. 
(1960): On the fractionation of complex components of Mycobacterium tuberculosis and their biological properties. Japan. J. Med. Sci. Biol., 13, 121-129.

Turk, J. L. AND STONE, S. H. (1963): Implication of the cellular changes in lymph nodes during the development and inhibition of delayed hypersensitivity. In Amos and Koprowski's, Cell Bound Antibodies, Wistar Inst. Press, Philadelphia, 51-60.

UHR, J. W. (1965) : Passive sensitization of lymphocytes and macrophages by antigen-antibody complexes. Proc. Nat. Acad. Sci. U. S. A., 54, 1599-1606.

UshibA, D., NAKAe, T., AkiYama, T. AND Kishimoto, Y. (1966): Characterization of "clearance" factor and cellbound" antibody in experimental typhoid. J. Bacteriol., 91, $1705-1712$.

WAALER. E. (1956): The influence of foreign antigen (typhoid-paratyphoid-vaccine) upon BCGinfection in guinea pigs. Acta Pathol. Microbiol. Scand., 38, 466-480.

WALlace, J. G. (1961): The heat resistance of tubercle bacilli in the lungs of infected mice. Am. Rev. Resp. Diseases, 83, 866-871.

Wattiaux, R., Wibo, M. AND Baudhuin, P. (1963): Influence of the injection of Triton WR-1339 on the properties of rat liver lysosomes. Ciba Found. Symp. Lysosomes, 176.

WeIsS, D. W. (1959): Vaccination against tuberculosis with nonliving vaccines. I. The problem and its historical background. Am. Rev. Resp. Diseases., 80, 340-358, 495-509, 676-688.

WEISS, L. P. AND FAWCETT, D. W. (1953) : Cytochemical observations on chicken monocytes, macrophages and giant cells in tissue culture. J. Histochem. Cytochem., 1, 47-55.

White, R. G., Bernstocky, H., Johns, R. G. S. ANd Lederer, E. (1958) : The influence of components of $M$. tuberculosis and other mycobacteria upon antibody production to ovalbumin. Immunology, 1, 54-66.

Williams, C. A. AND Dubos, R. J. (1959): Studies on fractions of methanol extracts of tubercle bacilli. I. Fractions which increase resistance to infection. J. Exptl. Med., 110, 981-1004.

Windman, I., Artman, M. and Bekierkunst, A. (1965): Tissue metabolism in infection. Liver microsomal enzymes of mice and guinea pigs in experimental tuberculosis. Am. Rev. Resp. Diseases, 91, 706-712.

Yanagisawa, K., Katsuyama, S. AND Kanai, K. (1956): Some immunological aspects of tuberculin-desensitization in experimental tuberculosis of guinea pigs. Ann. Rep. Jap. Assoc. Tuberc. No. 1, 1-12.

Yoneda, M., Fukui, Y., AND Yamanouchi, T. (1965): Extracellular proteins of tubercle bacilli. V. Distribution of $\alpha$ and $\beta$ antigens in various mycobacteria. Biken Journal, 8 , 201-223.

Yoneda, M., Fukui, Y., Yamanouchi, T. AND HoRI, M. (1966) : Immunogenic activity of an extracellular product of BCG in experimental tuberculosis in CF-1 mice. Symposium on the immunologic and allergenic antigens of mycobacteria. Sept. 4-7, Prague.

Youmans, G. P. (1957) : Acquired immunity in tuberculosis. J. Chronic Diseases, 6, 606-632. Youmans, G. P. (1963) : The pathogenic "atypical" mycobacteria. Ann. Rev. Microbiol., 17, 473-494.

Youmams, G. P. And Youmans, A. S. (1957) : The measurement of the response of immunized mice to infection with Mycobacterium tuberculosis var. hominis. J. Bacteriol., 78, 318-329.

Youmans, G. P. AND Youmans, A. S. (1962 a) : Effect of mycosuppressin on the course of experimental tuberculosis in mice. J. Bacteriol., 84, 701-707.

Youmans, A. S. AND Youmans, G. P. (1962 b) : Effect of mycosuppressin on the respiration and growth of Mycobacterium tuberculosis. J. Bacteriol., 84, 708-715.

Youmans, A. S. AND Youmans, G. P. (1964a): Further studies on a labile immunogenic particulate substance isolated from Mycobacterium tuberculosis. J. Bacteriol., 87, 278-285.

Youmans, A. S. AND Youmans, G. P. (1964 b) : Effect of mitochondrial stabilizers on the immunogenicity of the particulate fraction isolated from Mycobacterium tuberculosis. J. 
Bacteriol., 87, 1346-1354.

Youmans, A. S. AND Youmans, G. P. (1964 c) : Nature of the labile immunogenic substance in the particulate fraction isolated from Mycobacterium tuberculosis. J. Bacteriol., 88, 10301037.

Youmans, G. P. AND Youmans, A. S. (1965) : Effect of mycobacterial cell components upon susceptibility of mice to infection with M. tuberculosis. Proc. Soc. Exptl. Biol. Med., 120, 656-660.

YoumANS, AND YoumANS, G. P. (1965 b): Immunogenic activity of a ribosomal fraction obtained from Mycobacterium tuberculosis. J. Bacteriol., 89, 1291-1298.

Youmans, G P. AND Youmans, A. S. (1965 c) : Nonspecific factors in resistance of mice to experimental tuberculosis. J. Bacteriol., 90, 1675-1681.

Youmans, A. S. AND YoumAns, G. P. (1966 a) : Preparation of highly immunogenic ribosomal fractions of Mycobacterium tuberculosis by use of sodium dodecyl sulfate. J. Bacteriol., 91, 2139-2145.

YoumANS, A. S. AND YoumAns, G. P. (1966 b): Effect of trypsin and ribonuclease on the immunogenic activity of ribosomes and Iibonucleic acid isolated from Mycobacterium tuberculosis. J. Bacteriol., 91, 2146-2154.

Youmans, G. P., Millman. I. ANd Youmans, A. S. (1955): The immunizing activity against tuberculous infection in mice of enzymatically active particles isolated from extracts of Mycobacterium tuberculosis. J. Bacteriol., 70, 557-562.

Youmans, G. P., Parlett, R. C. AND Youmans, A. S. (1961): The significance of the response of mice to immunization, with viable unclassified mycobacteria. Am. Rev. Rest. Diseases, 83, 903-905.

Youmans, A. S., Youmans, G. P. AND Millman, I. (1957) : Immunogenicity of particles isolated from Mycobacterium tuberculosis. Proc. Soc. Exptl. Biol. Med., 96, 762-768.

ZEYA, H. I. AND SPITZNAGEL, J. K. (1966 a) : Cationic proteins of polymorphonuclear leukocyte lysosomes. I. Resolution of antibacterial and enzymatic activities. J. Bacteriol., 91, 750-754.

ZEYA, H. I. AND SPITZNAGEL, J. K. (1966 b) : Cationic proteins of polymorphonuclear leucocyte lysosomes. II. Composition, properties, and mechanism of antibacterial action. J. Bacteriol., 91, 755-762.

ZUCKER-FrENKLIN, D. AND HiRsCh, J. G. (1964) : Electronmicroscope studies on the degranulation of rabbit peritoneal leucocytes during phagocytosis. J. Exptl. Med., 120, 569-576. 